\title{
Çevik Yönetime Dair Bazı Tespitler: Yazılım Sektöründe Hazırlanan Raporlar Kapsamında Dönemsel Bir Analiz
}

\author{
Some Determinations Regarding Agile Management: A Periodic Analysis within the Scope of Reports \\ Prepared in the Software Industry
}

\author{
Muhammet Tuğrul ÖZEN \\ Doktorant, Çă Üniversitesi, SBE, \\ Işletme Yönetimi A.B.D., mtugrul.ozen@gmail.com \\ https://orcid.org/0000-0002-1671-5823
}

Makale Başvuru Tarihi: 02.02.2021

Makale Kabul Tarihi: 05.06.2021

Makale Türü: Araştırma Makalesi

\author{
Murat KOÇ \\ Doç. Dr., Çăg Üniversitesi, IIIBF \\ Uluslararası İsletme Yönetimi Bölümü, \\ muratkoc@cag.edu.tr \\ https://orcid.org/0000-0002-3848-3111
}

\begin{abstract}
ÖZET
Anahtar

Kelimeler:

Çevik Yönetim,

Çevik Yaklaşım,

Çevik Kültür,

Yillık Çevik

Durum Raporu,

VUCA,

VUCA (Volatility Uncertainty Complexity Ambiguity), bizi bugünlere getiren doğruların yarına götürmeyeceğini ifade eden bir akronim terim olmakla birlikte, VUCA ortamı iş hayatında birçok paradigma değişikliğini getirecek bir geleceğe gebe görünmektedir. VUCA ortamından organizasyonun çıkarlarını maksimum faydaya dönüştürerek çıkmak için yönetim ve iş yapma biçimlerinin "çevik" bir yaklaşıma evrilmesi gerekliliği düşünülmektedir. Çevik yaklaşım dış ortamdaki her türlü değişikliğe adapte olabilecek yetkinliği içinde barındıran proaktif eylemler bütünüdür. Çevik olabilmek; dış ortamdaki her türlü belirsizliği her an okuyabilme, anlamlandırabilme gayreti ile reaksiyon hızını sıfira indirecek refleks yeteneğimizi artırabilme çabası içinde olmak demektir. Her sene özveri ile yayınlanan "Yıllık Çevik Durum Raporu (Annual State of Agile Report)" çevik yönetim ile alakalı birçok konuyu ele alarak doğrudan uygulayıcıların tecrübelerini anlama firsatı sunan, geçmişe dayalı bilgi birikimli çalışmalar ve raporlar silsilesidir. Bu çalışmada, çevik dönüşüm tecrübesi yaşamış katılımcıların yıllar içerisinde verdiğ i yanıtlar incelenmiş, gelecek dönemin iş ve ticaret anlayışının değer kavramları ile yeniden yorumlanarak "müşteri deneyimi", merkezli bir çevik dönüşüm süreci modeli oluşturulmuştur. Çalışmadaki model önerisi çevik yaklaşım ve dönüşüm sürecini benimsemek isteyen işletmelerin karşılaşabilecekleri majör noktalara dikkat çekmek ve sürecin etkin bir şekilde sonuçlanması için gerekli koşulların tesis edilmesini tavsiye eden bir rehber niteliğinde olduğu düşünülmektedir.
\end{abstract}

Keywords:

Agile Management,

Agile Approach,

Agile Culture,

Annual State of

Agile Report,

VUCA,

\section{ABSTRACT}

VUCA is an acronym term that expresses the today's truths that would not lead to carry us to tomorrow, it seems to have a future that will bring many paradigm changes in business life. In order to get out of the VUCA environment by transforming for the interests of the organization to the maximum benefit, it is considered that management and business methods should evolve into an "agile" approach. Agile approach, it is a set of proactive actions that include the capability to adapt to all kinds of changes in the external environment. To be agile means being able to read and make sense of all kinds of uncertainties in the external environment at any time and in an effort to increase our reflex ability that will reduce the reaction speed to zero. The "Annual State of Agile Report", which is published devotedly every year, is a series of studies and reports based on past knowledge that offers the opportunity to understand the experiences of practitioners directly by addressing many issues related to agile management. In this study, the responses given by the participants who have experienced agile transformation over the years were examined, reinterpreting the business and commerce understanding of the next period with the value concepts, an agile transformation process model based on "customer experience" was created. The model proposal in the study is considered to draw attention to the major points that businesses who want to adopt the agile approach and transformation process and to be a guide that recommends the establishment of the necessary conditions for the effective conclusion of the process. 


\section{GÍRİş}

Y1kıcı bir inovasyon olarak kabul edilebilecek internetin hayatımıza girmesiyle bilgi üretim ve yayılım hızı katlanmış, ticari, ekonomik, toplumsal, çevresel ve kültürel yaşama dair hemen her alandaki standart, kabul ve doğrular derinden etkilenmiştir. Teknoloji ve iletişim araçlarının son 30 yıldaki devrimsel gelişimi, birçok alandaki tekel gücünü sarsmış, lokal bir işletmedeki üretilen ürünün, dünyanın farklı bir ucuna çok uygun maliyetlerle sağlayabilecek araçlar ile ticaretteki rekabet en üst boyutlara ulaştırmıştır. Diğer taraftan, internet tabanlı sosyal medya platformları başta olmak üzere, herhangi bir ürünün çevrimiçine girmesi ve tüketici ile buluşması dakikalar seviyesine inmiş, aynı anda talep ve siparişe dönüşmesine imkân sağlayacak yapıya ulaşmıştır.

2020 yılı öncesine kadar global pazar ve piyasalardaki makro ekonomik dengede; ticari faaliyetlerde, emtialar için fiyatlamayı ve değerlemeyi ifade eden endeksler arasında belirsizlikler ile birlikte öngörülebilir bir ilişki vardı. Ancak günümüzde bu ilişki seviyesi; pandeminin etkisi ile ortaya çıkan talep ve arz şokları, tedarik zinciri süreçlerini etkileyen bir krize dönmesi, ülkelerin salgının hızını kesebilmek için aldığı "evde kal" uygulamalarının tüketim ve üretim süreçlerini etkilemesi, yine ülkelerin aldıkları ihracat ve ithalat kısıtlamaları, ekonomik döngüyü sağlayabilmek adına ülkelerin tüketim ve üretimi yeniden canlandırabilmek için yapmış olduğu para ve mali politikalardaki vergi ötelemesi, düşük gelirli ailelere para desteği, düşük faizli kredi imkânı vb. birçok uygulama, döviz kur belirsizliği ve kıymetli madenlere doğru dönen bireysel yatırım kararları gibi çoğaltılabilecek çok sayıda örnek, içinde bulunduğumuz bu kaotik dönemi, VUCA (değişken ve dalgal1, belirsiz, karmaşık, muğlak ve şüpheli) ortamı olarak tanımlamak yerinde bir değerlendirme olacaktır.

Bizi bugünlere getiren doğruların yarına götürmeyeceğini ifade eden VUCA ortamı, gelecek iş hayatında birçok paradigma değişikliğini getirerek organizasyonları gerekli hazırlıkları yapmaya zorlamaktadır. Stratejik, operasyonel ve taktiksel planlara ait temel varsayımların VUCA ortamından etkilenmesi, dijital çağın oluşturduğu dönüşüm baskısı, işgören motivasyonunu önemseyerek organizasyonları değişen koşullara daha adaptif, hızlı, esnek, müşteri değerini ön planda tutacak, organizasyonun bütünsel çıkarlarını maksimum faydada tutabilmek için yönetim ve iş yapma biçimlerimizi “çevik" bir yaklaşıma evirmesi gerekliliği oluşmaktadır.

Yazılım sektörünün proje yönetim metodolojisi olarak literatüre giren "çevik yaklaşım” zaman içerisinde felsefe, yöntem, metolojinin gelişmesi ve genişlemesi ile değer üreten tüm organizasyonlara hitap etme özelliğine kavuşmuştur. Yıllar içerisindeki sürekli ve düzenli çevik dönüşüm sürecinin yazılım sektöründe kayıt altına alınıp, raporunun sunulduğu "Yıllık Çevik Durum Raporu" sadece yazılım sektörünün değil, çevik dönüşümü benimseyen birçok organizasyonun karşılaşabileceği temel dinamiklere, yönetsel unsurlara dikkat çekmektedir. Bu çalışmada, açık kaynaklarda yer alan "Yıllık Çevik Durum Raporu"nun 2015-2020 yılları arasında yazılım profesyonellerine sorulan sorular ve alınan yanıtlar bir araya getirilmiş, analiz edilmiş ve incelemeler sonunda çevik temel dinamikleri ve gelecek organizasyonlarının ihtiyaç duyacağı kriterleri de içeren bir dönüşüm modeli oluşturulmuştur.

Çevik yaklaşımın güncel, gelişen yapısını kavramak ve Türkçe literatürde çevik dönüşüm sürecine ait yönetsel argümanlara ilişkin çok fazla yayın olmaması bu çalışmanın ortaya çıkarılmasının temel motivasyonlarındandır. Organizasyonların çevik dönüşüm sürecinde yaşamış oldukları tecrübeleri tespit etmek; katma değer sağladığı alanları görmek, zorlandıkları alanlara dikkat çekerek öğrenme ve uyum maliyetlerini minimize etme gayretiyle oluşturulmuş bu çalışmanın çevik dönüşüm süreçlerindeki kritik noktaları belirlemeyi hedefleyen rehber bir kaynak niteliğinde olması amaçlanmıştır.

Çalışmamızda, "Müşteri Deneyimi" çevik dönüşüm sürecinden temel beklenti olarak belirlenmiş, analiz ve değerlendirmeler sonucu dönüşüm sürecinin 7 ana unsuru ortaya çıkarılmıştır. Bu ana unsurların, doğrudan iş hayatındaki pratik uygulayıcıların tecrübelerinden elde edilmesi, dönüşüm ve uygulama süreçlerindeki darboğazlar, faydalar, güçlükler ve geleceğe dair öngörüler 1şı̆̆ında belirlenmesi, okuyucuların sürece başlamadan karşılaşabilecekleri kritik noktaları gösterir özellikte bir referans olacağı ve literatüre katkı sağlayacağ düşünülmektedir.

\section{2. ÇEVIK YÖNETIM YAKLAŞIMI}

Gelecek tahmini ve buna bağlı olarak geliştirilen strateji ve hedeflerin temel referans noktası yoğunlukla geçmiş yıllara ait veriler ve tecrübelerdir. Gelecek tahmininde ve stratejik çalışmalarda, geçmiş veriler arasında korelasyon ve bağlantılardan yeni yol ve yöntemler ortaya konulur ve geleceğe dair iş modelleri geliştirilir. 
Geçmiş bilgi ve tecrübelerimiz, içinde bulunduğumuz durum ve zaman, geleceğimizi tahmin etmede bize bir fayda sağlamıyorsa VUCA ortamının içinde olduğumuzu gösteren bir işarettir. Çevik yönetim yaklaşımının benimsenmesi ve çevik dönüşüm ihtiyacına götüren argümanların anlaş1lması için kavramsal olarak VUCA yaklaşımına temas edilecektir.

Şirketlerin etki alanının dışında bulunan bilgi ve teknoloji alanındaki gelişmeler, tüketici ihtiyaç, istek ve taleplerinin farklılaşması, finansal alandaki krizlerle oluşan dalgalı bir ekonomik çevrenin getirmiş olduğu zorlayıcı şartlar üzerine, son dönemdeki salgın kaynaklı pandemi ortamı, şirketleri daha belirsiz, öngörülemeyen ve karmaşık bir gelecek içinde bırakmıştır. İş ve yönetim kültürünün maruz kaldığı bu durum, geleceğe dair tüm belirsizleri ve tahmin edilemeyen kaotik yapıyı tanımlamaya yarayan güncel kavramlardan birisi olan VUCA ile açıklanabilir. 2020-2021 sürecini pandeminin de etkisi ile VUCA ortamını derinleştirdiği söylenebilir.

VUCA, 1987 y1lında California Üniversitesi Profesörü Warren Bennis ile MIT'de görevli akademisyen Burt Nanus tarafindan oluşturulmuş bir kavramdır. Özellikle, 1990'lı yıllarda Soğuk Savaş sonrası yıkılan bloklar ve geleceğe dair gerçekleşecek olayların tahmin edilebilirliğinin zorlaştığı bir ortamı tasvir edebilmek için ABD ordusunun sıkça kullandığı ve global olarak bilinirliğini artırdığ 1 bir terimdir (Barber, 1992:8). Akronim bir terim olan VUCA, şu açılımla ifade edilebilir; Volatility: Değişkenlik/Dalgalanma, Uncertainty: Kesin Olmama Durumu, Complexity: Karışıklık/ Karmaşa, Ambiguity: Muğlaklık ve Şüphe.

Çeviklik, belirli bir düzen içerisinde olmayan bir çevreyle ve beklenmedik / öngörülemeyen değişikliklerle başa çıkabilme becerisi, yetkinliği olarak ifade edilebilir (Devor vd.,1997:814). Wyscoski (2014), iş süreçlerinde hedefin açık ancak çözüm ve nasıl ulaşılacağı konusunda risk, belirsizlik ve karmaşıklık varsa "Çevik Proje Yönetimi" kullanılması, sonuca ulaştırmada yardımcı olabileceğini ifade etmiştir. Çevik metodolojide, döngüden döngüye sürekli bir değişim süreci gerçekleşecek ve eksiksiz çözüme bir adım daha yaklaşacak yakınsamayı yaratılabilecek bir tasarım mevcuttur (Wscoski, 2014:405).

Teknolojik gelişim ile birlikte gelişen değişken gereksimler ve müşterilerin özel isteklerine göre ürün geliştirme sürecinde, gelişmiş hız ve yüksek kaliteyi çevik yöntemler ile sağlayabilmenin mümkün olabileceği ifade edilebilir (Flora vd., 2014:43). Gablas vd. (2018), küçük ve orta ölçekli işletmelerde uygulanan klasik proje yönetim yaklaşımının proje yürütme esnasında yönetim tarzında değişiklik ile çevik yönetim yaklaşımlarının benimsenerek yürütülebilirliği 119 proje yöneticisine sorulmuştur. Alınan yanıtlarda, katılımcıların \%81'i yönetim tarzındaki değişiklik ile projenin başarıyla sonuçlanacağını bekledikleri ifade edilmiş, ayrıca dönüşüm sürecinin nasıl yapılacağına dair ek çalışmaların yapılma gerekliliği paylaşılmıştır (Gablas vd., 2018:50).

Çevik yaklaşım, bir proje yönetim modelinden çok daha fazlasıdır. Çevik yaklaşımı, bir kavramsal çerçeve ve düşünme yolu olarak nitelemek mümkündür. İç ve dış müşteri kavramları ile sürecin her bir aşamasına katma değer sunan ve yeniliklere adaptasyonu yüksek olan gelişim odaklı bireylerden oluşan bir kültür ve sistem olarak ifade edilebilir. Bu yaklaşım, hızlı teslimatı; doğru kaliteyi, düşük maliyeti ve rekabetçi fiyatı, yüksek müşteri servis seviyesi ile perçinleştirerek müşterilerine daha iyi hizmet sunma odakl1, vizyon, kültür ve stratejilerin birleşimidir (Tanoğlu, 2018:33).

"Çevik yaklaşım” dış ortamdaki her türlü değişikliğe adapte olabilecek yetkinliği içinde barındıran proaktif eylemler bütünüdür. Çevik olabilmek; dış ortamdaki her türlü belirsizliği her an okuyabilme, anlamlandırabilme gayreti ile reaksiyon hızını sıfıra indirecek refleks yeteneğimizi artırabilme çabası içinde olmak demektir. Çevik yaklaşım; bölümler arası yüksek işbirliğine ve iletişime, şirket içi şeffaflık seviyesinin yükselmesine ve geri bildirime, yeni fikir ve önerilere bilinçli farkındalık ile önyargısız yaklaşma ve ortak hedeflere bağlı projelerle iyileştirme ve geliştirme çabasıyla bir takım çalışma kültürü içinde olmak demektir.

Çevik yönetim yaklaşımını benimsemiş organizasyonlar, çok hızlı ve sık bir şekilde gerek kendilerini gerekse iş yapış şekillerini yeniden tasarlayıp, kurgulayabilen, bu davranışı sürekli ödüllendiren ve gücünü farkındalık ve takımlarına ilham veren liderlik anlayışından alan yapılardan oluşurlar (Çevikoğlu, 2019:5). Çevik takımlar, sahip oldukları yetkinlik, sorumluluk, donanım, bütçe ve otonom yapının getirdiği altyapı ile hız ve adaptasyonu en iyi şekilde harmanlama becerisine sahip olabilmektedir. Çevik yöntemlerin deneyerek öğrenme, multidisipliner takım yapısı, özdeğerlendirme yapılan retrospektif toplantıları ile sürekli öğrenme süreci gelişimin anahtarı niteliğindedir.

İnovasyon kavramına hizmet-baskın (Service-Dominant) mantık perspektifinden bakıldığında, inovasyon bir şeyler icat etmekle ilgili değil, birlikte değer yaratımı için sistemler geliştirmekle ilgili olduğu ve ürünlerin (asıl) işlevinin hizmet sunmakla ilişkilendirilmesi ifade edilebilir (Vargo ve Lusch, 2017:54; Findsrud, 2020:190). Benzer bir yaklaşımla, hizmet inovasyonu, farklılaşma ve büyümenin ana motoru olarak nitelendirilmektedir 
(Helkkula vd. 2018:284). Müşteri deneyimini merkeze alan hizmet-baskın odaklı yaklaşımdaki beklentilerin çevik yönetim felsefe ve konsepti ile örtüşmekte olduğu ifade edilmiştir (Findsrud, 2020:190).

McKinsey Quarterly dergisi Aralık 2015 sayısında, yazarlar tarafından çevik organizasyonların paradoksal olarak hem istikrarlı (esnek, güvenilir ve verimli) hem de dinamik (hızlı, çevik ve adaptif) olmayı öğrendikleri paylaşılmış ve bu paradoksun üstesinden gelmek için şirketlerin, organizasyon yapısı, yönetişim düzenlemeleri ve süreçleri yeniden tasarlaması gerektiği vurgulanmıştır. Aynı zamanda, yeni zorluklara ve firsatlara hızla adapte edilebilecek daha gevşek, daha dinamik unsurlar yaratmaları gerektiği ifade edilmiştir (Aghina vd., 2015:1).

Bal (2020), çevik dönüşüm sürecini kültürel boyut, teknoloji boyutu ve organizasyon model boyutu olarak birbiri ile bağlantılı üç majör boyutta değerlendirmiştir. Dönüşüm kararı almış şirket yönetimi, boyutların hemen hemen tamamında paralel ve eş zamanlı çalışmalar yapması ile çevik dönüşümden beklenen fayda sağlanmasını sağlayabilecek, aksi durumda, dönüşüm süreci başarısızlığa uğrama riski taşıyabilecektir. Başarılı yönetsel çevik adımlar sonrasında, şirketlerin yetkilendirilmiş takım bazlı, daha şeffaf ve yalın süreçlere ve hiyerarşinin azaldığı bir organizasyona dönüşmüş olması beklenmektedir (Bal, 2020:3).

Müşteri talepleri ve çevresel koşulların olağanüstü bir hızla farklılaştığı, rekabet zorluk derecesinin organizasyonların üzerinde oluşturduğu bask1 ortamı, kısıtlı kaynakların etkin kullanma zorunluluğu organizasyonları yeni yönetsel anlayışları araştırmaya sevk edebilmektedir. Yönetsel felsefe ve metodolojiler bağlamında bugünümüzün ve geleceğimizin ihtiyaç duyabileceği güncel durum ve sorunlara karşı çevik yönetim yaklaşımının bir alternatif çözüm sunabileceği düşünülmektedir.

\section{1. Çevik Yönetim Yaklaşımı Kapsamında "Yıllık Çevik Durum Raporu”nun Önemi}

2020 y1lı başından itibaren ve dünya genelini saran pandemi dönemi, VUCA kavramının en somut örneklerindendir. İçinde bulunduğumuz döneme, doğru adapte olabilme ve her türlü olumsuz durumu kurumsal faydaya dönüştürecek eylemlerin temel referans noktasının çevik bir yönetim anlayışı teşkil eder. Çevik yönetim yaklaşımı, yönetim alanındaki yazının güncel konularından olmakla birlikte, gelecek ile ilgili her türlü belirsizliği bertaraf etmek için şirketler nezdinde de son yıllarda bilinirliği ve uygulanması artan bir yönetim biçimidir. Çevik yönetim yaklaşımını müşteri deneyimini en üst seviyede tutmak isteyen şirketlerin başarı anahtarlarından birisi olarak değerlendirmek mümkündür. Nitekim aşağıdaki bölümde detayları üzerinde duracağımız noktalardan birisi de çevik takımların başarı göstergelerinin başında müşteri memnuniyeti gelmektedir. Şirketlerin çevresini kuşatan etken faktörlerin VUCA ortamında olması, şirketlerin sürdürülebilir büyüme hedeflerine ulaşmasını daha da zorlaştırmaktadır. Bu zorluğun üstesinden gelebilecek yönetimsel felsefe ve çerçevenin temelini çevik yaklaşımın oluşturması önerilmektedir.

Çevik yaklaşımı benimseyen ve uygulayan şirketlerin, bu dönüşüm sürecini benimseme nedenleri ve yaşadıkları deneyimleri anlamak, çevik yönetim sürecine adapte olmak isteyen örgütlerin, yaşayacakları olası zorlukları ve elde edeceği faydaları doğrudan uygulayıcıların dilinden okumak önem arz etmektedir. Bu sebeple, 2007 yılından 2020 yılına kadar, her sene özveri ile yayınlanan "Yıllık Çevik Durum Raporu (Annual State of Agile Report)"; çevik yönetim ile alakalı birçok konuyu ele alarak doğrudan uygulayıcıların tecrübelerini anlama fırsatı sunan, geçmişe dayalı bilgi birikimli çalışmalar ve raporlar silsilesidir.

Y1llık Çevik Durum Raporu, her y1l CollabNet VersionOne tarafinda hazırlanmakta olup, yazılım profesyonellerine çevik eğilimler, en iyi uygulamalar ve çevik dönüşümlerinde başarılı olmalarına yardımcı olacak öğrenilen dersler hakkında derinlemesine bilgi sağlamaktadır. Bu raporlar silsilesi, yıllık ortalama 30004000 kişinin katılımı ile gerçekleşen dünyadaki en büyük, en uzun süreli ve en çok alıntı yapılan çevik anket haline gelmiştir. Yıllık Çevik Durum Raporu, 2007-2015 arasında katılımcılara sorulan soru ve alınan yanıtlar genel olarak yazılım sektörünün kapsamı içerisinde tutulmuştur. 2015 sonrası daha geniş anlamda katılımlar sağlanmış, soru kapsamlarını ve ifadelerini yenileyerek geniş kitlelere ulaşımlar sağlanmıştır. 2020 yılında yayınlanan son çalışmaya kadar başlangıçtan bu yana toplam katılımcı sayısı 40.000 kişiyi aşmış durumda, 6 farklı kıta ve en az 20 farklı sektörden katılım sağlanarak genel geçerlik seviyesini artırmış durumdadır (Stateofagile, 2020).

Çevik yönetim, bilindiği üzere yazılım proje yönetim modellerinden birisi olarak yaygın kullanımda iken, yönetim alanına felsefe ve vizyon sunan bir kavramsal çerçeve haline gelmiştir. Bu çalışmanın yönetim referanslı odak noktası gereği, Y1llık Çevik Durum Raporu'nun 2015-2020 yılları arasındaki dönem aralığında yanıtları alınan, çevik yönetimin faydaları, çevik yönetimin benimsenmesindeki zorluklar, çevik yönetimi 
benimseme nedenleri, çevik yönetimdeki başarı kriterleri ve çevik yönetimi tercih eden sektörlerin dağılımı üzerinde toplanan veriler üzerinden analiz ve değerlendirmelerde bulunulmuştur.

\section{3. ÇEVIK DÖNÜŞÜM SÜRECI VE YÖNETIM SÜRECİ İÇİNDEKİ YERİ}

Yönetim sürecine ait temel fonksiyonların (Planlama, Örgütleme, Yöneltme ve Denetim) yönetilen kurumun kamu/özel/kâr amacı gütmeyen bir organizasyon olmasından bağımsız bir şekilde etkin ve verimli şekilde yönetilmesi önem arz etmektedir. Kurumlar, sahip olduğu organizasyon yapısı, içinde bulunduğu sosyoekonomik çevre, şirketin ana faaliyetlerinin bulunduğu sektöre vb. birçok etken faktör farklı seviyelerde etkileşim ile yönetim fonksiyonlarından faydalanırlar.

VUCA ortamı içerisinde bulunan bir şirketin, kendisini geleceğe taşımak için sahip olduğu kaynaklar, temel yetkinlikler ve özellikler, şirketin iç ve dış çevresindeki güç dengelerinin değişmesinden kaynaklı yetersiz kalabilir. Şirketlerin sürdürülebilir bir şekilde varlığını devam ettirebilmesindeki anahtar rol olan müşteri deneyimini daha yüksek seviyelere çıkarabilmek için yönetim alanlarında mevcut uygulama ve bakış açılarına alternatif yöntem ve yaklaşımlar doğurmuştur. $\mathrm{Bu}$ yönetim dönüşümlerinden birisi de çevik yönetim yaklaşımıdır.

$\mathrm{Bu}$ bölümde, çevik yaklaşımın benimsenmesinin kurumsal faydaları, dönüşüm süresince yaşanan zorluklar, organizasyonların çevik yaklaşımı uygulamalarına neden unsurların neler olduğu, çevik dönüşüm performans parametreleri ve çevik uygulayıcıların bulundukları sektörlerin neler olduğu ele alınacaktır. Aşağıdaki tablolarda (Tablo 1-5) ve grafiklerde (Grafik 1-5) bulunan veriler, yıllık olarak yayınlanan 2015-2020 y1lları arasını kapsayan, 6 yıla ait "Yıllık Çevik Durum Raporu" raporlarından doğrudan alınmış, soru kalıpları/yanıtlar Türkçeye çevrilmiş ve tablo haline getirilmiştir. Yıllar içerisinde değişimi daha kolay analiz edebilmek adına tablolar grafik haline dönüştürülerek eklenmiştir.

\section{1. Çevikliği Benimsemenin Faydaları}

Çevik yönetim anlayışını ve çevik dönüşümü benimseyen şirketlerdeki uygulayıcılardan, 2015-2020 yılları arasında "Çevikliği Benimsemenin Faydaları" başlığı altındaki alınan yanıtlar aşağıdaki tabloda (Tablo 1. ve Grafik 1.) yansıtılmıştır. Bu bölümde, çevik anlayışı benimsemenin organizasyona sağlamış olduğu katkılar ve farkındalıklar, şirketlerin öncelikli hedeflerini, çözüm aradıkları konuları, iyileştirmek ve güçlenmek istediği alanlara da dikkat çeker nitelikte olduğu düşünülmektedir.

Anketlerde, "çevikliği benimsemenin faydaları" için yanıt aranırken katılımcılara birden fazla şıkkı tercih edilebileceği ifade edebileceği belirtilmiştir. 2015 yılından itibaren takip eden her senede katılımci profilinin genişlemesi ile birlikte, özellikle 2017 yılından sonra, verilen yanıtlardaki şiddet seviyesinin yıllar içerisinde azaldığı tahmin edilmektedir. Ancak, aynı yanıt başlıklar kendi aralarında minör değişikliklere uğradığı da ayrıca dikkat çekmektedir.

Tablo 1. Çevikliği Benimsemenin Faydaları

\begin{tabular}{|c|c|c|c|c|c|c|}
\hline Çevikliği Benimsemenin Faydaları & $\mathbf{2 0 1 5}$ & $\mathbf{2 0 1 6}$ & $\mathbf{2 0 1 7}$ & $\mathbf{2 0 1 8}$ & $\mathbf{2 0 1 9}$ & $\mathbf{2 0 2 0}$ \\
\hline Değişen öncelikleri yönetme yeteneği & $87 \%$ & $87 \%$ & $88 \%$ & $71 \%$ & $69 \%$ & $70 \%$ \\
\hline Proje görünürlüğü & $82 \%$ & $84 \%$ & $83 \%$ & $66 \%$ & $65 \%$ & $65 \%$ \\
\hline İ̧letme / BT uyumu & $75 \%$ & $77 \%$ & $76 \%$ & $65 \%$ & $64 \%$ & $65 \%$ \\
\hline Teslimat hızı / pazara çıkış süresi & $77 \%$ & $80 \%$ & $81 \%$ & $62 \%$ & $61 \%$ & $60 \%$ \\
\hline Takım morali /motivasyonu & $79 \%$ & $81 \%$ & $81 \%$ & $61 \%$ & $64 \%$ & $59 \%$ \\
\hline Ekip üretkenliğinde artış & $84 \%$ & $85 \%$ & $83 \%$ & $61 \%$ & $63 \%$ & $58 \%$ \\
\hline Proje risk azaltma & $76 \%$ & $78 \%$ & $74 \%$ & $47 \%$ & $50 \%$ & $51 \%$ \\
\hline Proje öngörülebilirliği & $79 \%$ & $81 \%$ & $75 \%$ & $49 \%$ & $52 \%$ & $50 \%$ \\
\hline Yazılım kalitesi & $78 \%$ & $79 \%$ & $75 \%$ & $47 \%$ & $47 \%$ & $46 \%$ \\
\hline Mühendislik disiplini & $72 \%$ & $73 \%$ & $68 \%$ & $43 \%$ & $42 \%$ & $44 \%$ \\
\hline Dağıtılmış ekipleri yönetme & $59 \%$ & $62 \%$ & $61 \%$ & $40 \%$ & $34 \%$ & $41 \%$ \\
\hline Yazılım sürdürülebilirliği & $68 \%$ & $70 \%$ & $64 \%$ & $33 \%$ & $39 \%$ & $35 \%$ \\
\hline Proje maliyetinde azaltma & & & $56 \%$ & $22 \%$ & $28 \%$ & $26 \%$ \\
\hline
\end{tabular}

Kaynak: Stateofagile, 2020. 
Grafik 1. Çevikliği Benimsemenin Faydaları

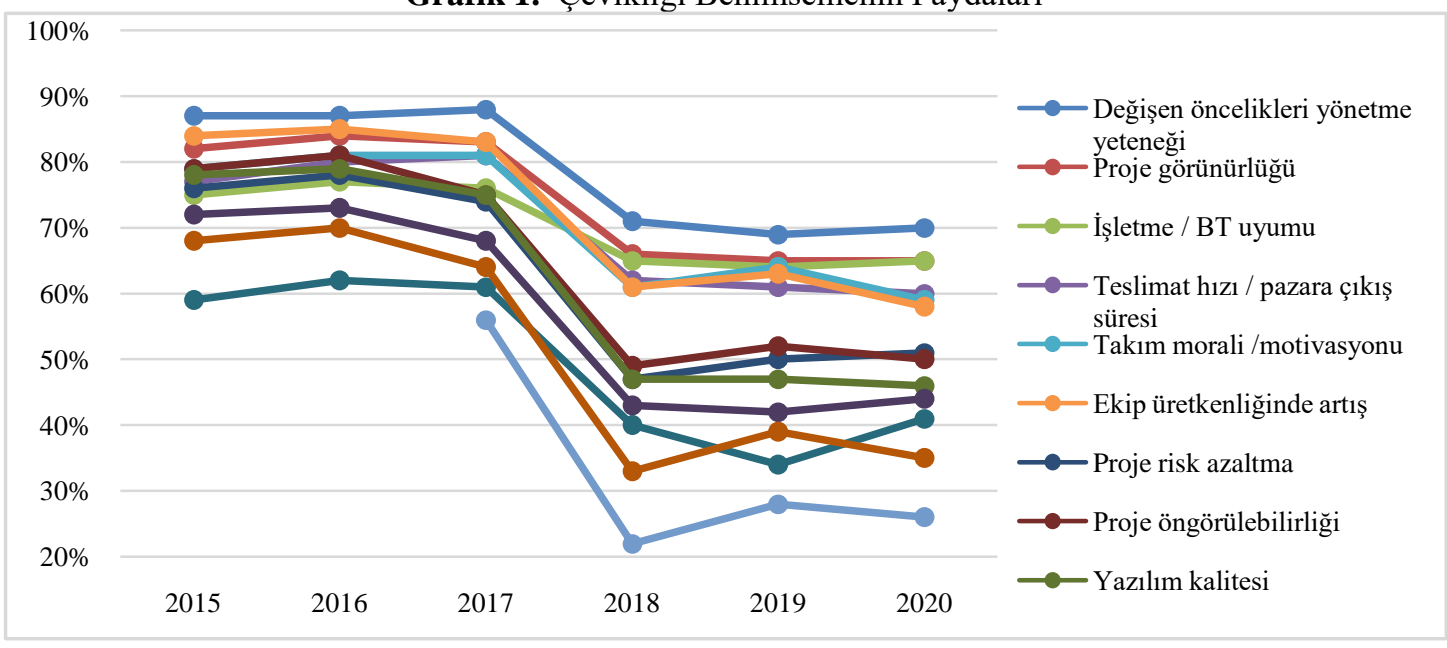

Kaynak: Stateofagile, 2020.

Y1llar içerisindeki fayda etkinliği en yüksek seviyede olan yanıt, "Değişen öncelikleri yönetme yeteneği” olarak ifade edilmiştir. Bu yanıt, çevik dönüşüm ruhuna ve yönetim felsefesine uygun beklenti ile dönüşüm sonrasında uygulayıcılar nezdinde elde edilen faydanın eşleşiyor olması, çevik dönüşümün somut katma değerlerinin organizasyon tarafından içselleştirilen önemli göstergelerindendir.

İnternet, teknoloji, iletişim araçları ve popüler kültürün etkisi ile trend ve alışkanlıkların kitlesel düzeyde çok hızlı değiş̧mesi ile ürün yaşam ömürlerini kısaltmış, sürekli farklılaşan tüketici istek, ihtiyaç ve taleplerini karşılayabilmede üreticilerin geleneksel model ve yapılar yerine alternatif yöntem ve metotlar geliştirmeye doğru zorlamaktadır. Bu sebeple, yönetsel seviyede "Değişen öncelikleri yönetme yeteneği" organizasyonların sürdürülebilirliğini sağlamak için hayati derecede önemli hale gelmektedir.

“Proje görünürlüğü”, herhangi bir projeye başlamadan önce proje süresince karşılaş1labilecek, her türlü getiri, risk, vaka, sonuç, kayıpların proje başlamadan öngörülmesi ve bu farkındalı̆̆ın proje plan sürecinde tespit edilerek ortaya konulmasıdır. Olabilecek tüm senaryoları öngörebilmek ve çözüm üretebilmek, çevik yönetimin temel dinamiklerinden olan katılımcı bir takım kültürü sonucudur.

Çevik dönüşümün alt boyutlarından bir tanesi de, dijital dönüşüm süreçleri ile etkisi düşük, birçok prosedürel süreçleri ortadan kaldırmaktır. Dijital dönüşüm, sistemsel altyapı ile doğru ve güvenilir verilerle karar alma sürelerini hızlandıran çok önemli araçlardandır. Çevik yönetimin benimsenmesi, dijital altyapı desteğinin olması ile işletme çalışanlarının bu noktadaki hızlı adaptasyonu çevik dönüşümden elde edilecek katkıyı daha yüksek seviyelere çıkartmayı sağlayacaktır. Bir diğer yönden, dijital dönüşümle, "İşletme ve BT arasındaki uyum" sağlanabilir, öğrenen organizasyon yaratarak çalışanların gerek kişisel gelişimleri gerekse işgörenlerin organizasyona olan katma değer hissi takım moral ve motivasyonunu da artıran bir faktör olarak değerlendirilebilir.

21.yy müşteri/tüketici portföyü satın alma gerçekleştireceği herhangi bir üründe, kalite, fiyat beklentisinin yanından hızlı teslim alma öncülünü de dikkate almaktadır. Gelişen teknoloji ile üretim gerçekleştirebilmenin kolaylaşması ve maliyetlerin düşmesi, şirketleri müşteri nezdinde farklı değer oluşturacak ayrıcalıklar sunmaya zorlamaktadır. Ürün yaşam döngüsünün olabildiğince kısalması, farklı çeşit ürün ve hizmeti en hızlı şekilde tedarik etme süreci işletmelerin çevikliği benimsemesini sağlayan bir itici güç olmaktadır. Bu noktadan hareketle, çevikliği içselleştirmenin organizasyona olan bir diğer önemi katkısı, üretilen "Ürünlerin pazara çıkış süresi"ni ve "Teslimat süresini hızlandırmak" olarak ifade edilebilir. Çevikliği benimsemedeki faydalar arasındaki öncelik sırasının eski yıllara nazaran ön sıralara gelmesi, çevik yaklaşım anlayışının gelecek yıllarda da kritik öneme sahip olacağı düşünülebilir.

Şirketin dış dünyasında rekabetle başa çıkabilmek müşteri memnuniyetini artırma hedefi ile alınan aksiyonlar, işletme içerisinde birçok kaynağın etkin ve verimli kullanılması ile zıt süreçler içerebilmektedir. Farklı her bir ürün, işletmede üretim değişimi, kurulum zamanı (setup time), kalite kayıpları, hat kapasite kaybı, birim zamandaki üretim ve işçilik giderlerinin yükselmesini de beraberinde getirecektir. İşletmeler bu süreçleri daha etkin ve verimli yönetilmek için çevik yaklaşımla değer yaratmayan süreçlerin ortadan kaldırılması için 
yöntemler geliştirmeyi hedeflerler. Bu sebeple, “üretkenlik” çevik yönetimin benimsenmesindeki önemli argümanlardandır.

\section{2. Çevik Yönetimin Benimsenmesinde Yaşanan Zorluklar}

Çevik yönetim anlayışı, şirketin uçtan uca tüm süreç ve uygulamalarını etkileme gücüne sahip bir düşünce sistemi ve yaklaşımdır. Çevik dönüşümü benimseyen örgütler; yeni bir yönetim kültürü, uygulama farklılıklarını kabul ederler. Özellikle, VUCA ve Covid-19'un kesişimi ile kurumların karşılaştığı ticari, ekonomik ve yönetimsel zorluklar, şirketleri çevik yönetim yaklaşımını uygulama noktasında zorunlu bir tercih noktasına taşıyacağı ifade edilebilir. Bu sebeple, 2015-2020 yılları arasında yayınlanan "Çevikliği Benimserken ve Ölçeklendirirken Yaşanan Zorluklar" başlığı altındaki yanıtlar, dönüşüm sürecindeki organizasyonların karşılaşacağı içsel ve dışsal yönetsel faktörlerin ön okumasının yapılması adına büyük önem taşımaktadır. Bu faktörler; çalışan, yönetim/lider desteği, organizasyon kültürü, bilgi, uygulama ve deneyim eksikliği, çevik kültürü kavrama eksikliği, alışkanlıklar ve değişime karşı direnç olarak genelleştirilebilir. Anket çalışmasında "Çevikliği Benimserken ve Ölçeklendirirken Yaşanan Zorluklar" nelerdir sorusuna yanıt aranırken, katılımcıların birden fazla tercihte bulunabilmesine olanak sağlanmıştır.

Tablo 2. Çevikliği Benimserken ve Ölçeklendirirken Yaşanan Zorluklar

\begin{tabular}{|c|c|c|c|c|c|c|}
\hline Çevikliği Benimserken ve Ölçeklendirirken Yaşanan Zorluklar & 2015 & 2016 & 2017 & 2018 & 2019 & 2020 \\
\hline Değişime karşı genel organizasyon direnci & $36 \%$ & $38 \%$ & $43 \%$ & $46 \%$ & $48 \%$ & $48 \%$ \\
\hline Liderlik katılımının yetersizliği & & & & & & $46 \%$ \\
\hline Ekipler arasında tutarsız süreçler ve uygulamalar & & $38 \%$ & $31 \%$ & $34 \%$ & $35 \%$ & $45 \%$ \\
\hline Çevik değerlerle çelişen organizasyon kültürü & $42 \%$ & $46 \%$ & $63 \%$ & $53 \%$ & $52 \%$ & $44 \%$ \\
\hline Yetersiz yönetim desteği ve sponsorluk & $38 \%$ & $38 \%$ & $45 \%$ & $42 \%$ & $44 \%$ & $43 \%$ \\
\hline Çevik yöntemlerle ilgili beceri / deneyim eksikliği & $44 \%$ & $41 \%$ & $47 \%$ & $41 \%$ & $40 \%$ & $41 \%$ \\
\hline Yetersiz eğitim ve öğretim & $30 \%$ & $27 \%$ & $34 \%$ & $35 \%$ & $36 \%$ & $39 \%$ \\
\hline İşletme / müşteri / ürün sahibi eksikliği & & & $41 \%$ & $31 \%$ & $32 \%$ & $36 \%$ \\
\hline Geleneksel geliştirme yöntemlerinin yaygınlığı & & & $34 \%$ & $30 \%$ & $28 \%$ & $30 \%$ \\
\hline Parçalı takımlar ve proje ile ilgili veriler / ölçümler & & & $20 \%$ & $24 \%$ & $26 \%$ & $29 \%$ \\
\hline Minimum işbirliği ve bilgi paylaşımı & & $25 \%$ & $19 \%$ & $21 \%$ & $24 \%$ & $22 \%$ \\
\hline Mevzuata uygunluk veya hükümet sorunu & & & $15 \%$ & $14 \%$ & $16 \%$ & $16 \%$ \\
\hline Bilmiyorum & $6 \%$ & $5 \%$ & $2 \%$ & & & \\
\hline Geleneksel şelale süreçlerini takip etmek için dış baskı & $37 \%$ & $36 \%$ & & & & \\
\hline Daha geniş bir organizasyon veya iletişim sorunu & $33 \%$ & $30 \%$ & & & & \\
\hline Ekibin çevikliği takip etme isteksizliği & & $30 \%$ & & & & \\
\hline Çalışmaya sürekli öncelik verememe & & $28 \%$ & & & & \\
\hline Etkisiz yönetim işbirliği & & $34 \%$ & & & & \\
\hline
\end{tabular}

Kaynak: Stateofagile, 2020

Başarılı bir çevik dönüşüm süreci, doğru yetkinliklere ve becerilere sahip bireylerden oluşan takımları oluşturma, takımların değişim sürecine uyumu ve motivasyonu yönetebilme, bilgi ve yönlendirmelerle kişisel ve kurumsal gelişime katma değerli süreç ve uygulamaları yönetebilecek vasıflara sahip çevik liderlere ihtiyaç duyar. En son gerçekleştirilen araştırma sonuçlarında çevikliği benimseme ve ölçeklendirmede yaşanan zorluklar arasında "Liderlik katılımı yetersizliği" yanıtı en üst sıralarda yer almaktadır.

Çevik liderin sorumluluk ve etki alanları dikkate alındığında, 2020 yılı öncesinde alınan bazı yanıtlar: "Ekipler arasında tutarsı süreçler ve uygulamalar" "Çevik yöntemlerle ilgili beceri / deneyim eksikliği", "Minimum işbirliği ve bilgi paylaşımı", "Daha geniş bir organizasyon veya iletişim sorunu”, "Ekibin çevikliği takip etme isteksizliği”" dolaylı olarak görülen "Liderlik katılımı yetersizliği” ile ilişkilendirilebilir. 
Grafik 2. Çevikliği Benimserken ve Ölçeklendirirken Yaşanan Zorluklar

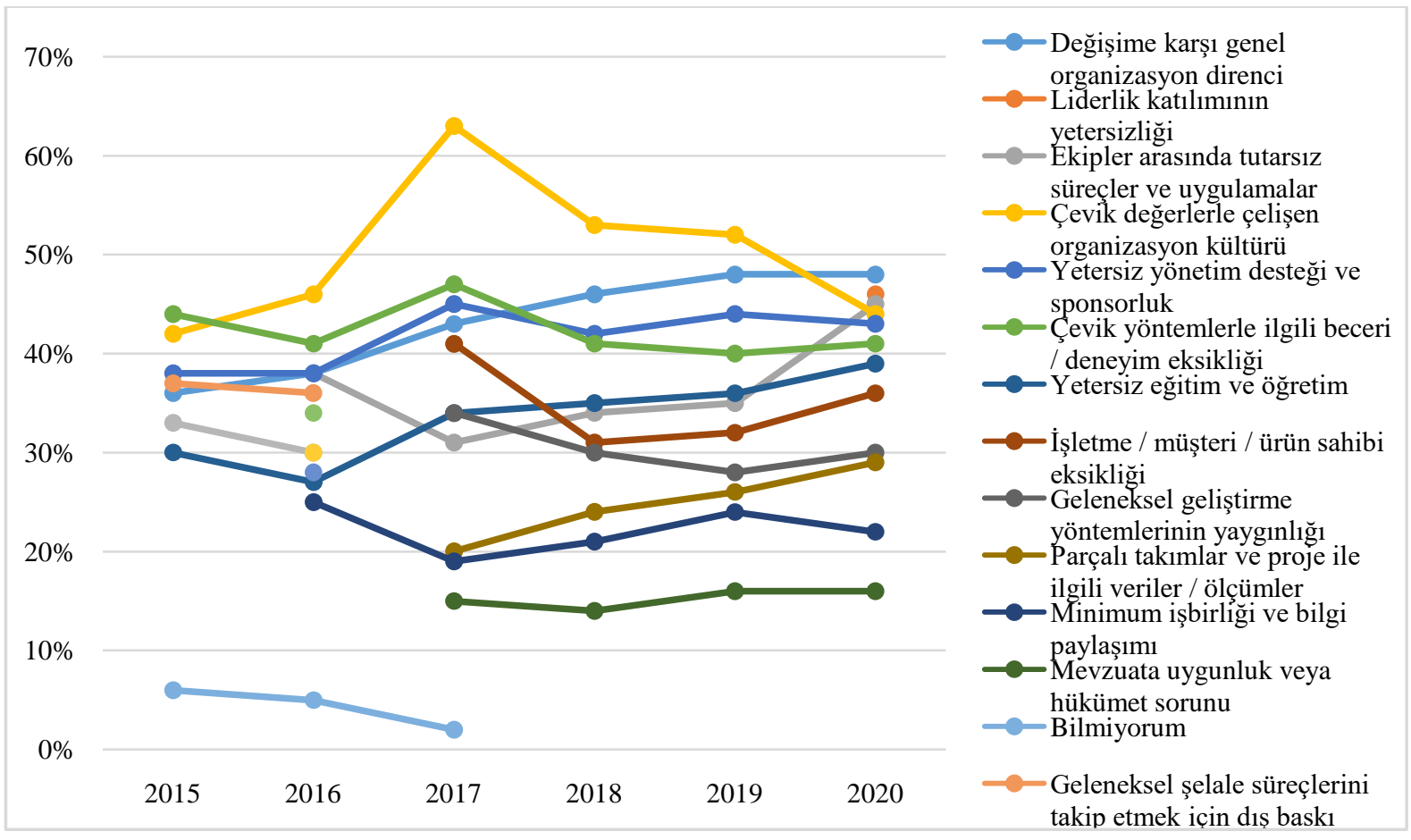

Kaynak: Stateofagile, 2020.

Çevik liderler, dönüşüm sürecinin örgüt tarafından içselleştirilmesi ve minimum kayıplarla dönüşümü sağlamak için anahtar rolde bulunan yönetici ve lider vasıflarını aynı anda taşıyan yönderlik sıfatına sahip olmalıdırlar. Çevik dönüşümde, organizasyon içerisindeki yeniden yapılanma ile birçok çalışanın görev ve sorumluluk alanları değişecek ve buna bağlı olarak bazı çalışanların eskiden sahip olduğu yetki ve gücün de etkilenmesi ile sonuçlanacaktır. Bu durum, motivasyon faktörlerini de göz önüne alarak takım içerisindeki dengeleri doğru regüle etme, çevik liderlerin en önemli sorumluluk alanlarından birisi olacaktır.

"Yetersiz yönetim desteği ve sponsorluk" hemen her y1l üst seviyelerde bulunan ve katılımcılar tarafindan çevik dönüşümün benimsenmesinde yaşanan zorluklar olduğu ifade edilmiştir. Takım içerisinde veya birey olarak çalışanlar, yaptıkları iş süreçlerinin üst yönetim tarafından maddi ve manevi boyutlarda desteklemesini bekler. Bu beklenti takımların özgüveni artırıcı bir faktör, motive edici bir tutum ve sorunlar karşısında çözüme destek olan bir güce dönüşebilecek özelliktedir. Yönetim desteği ve dışarıdan gelebilecek sponsorluk hizmeti eksikliği çalışma takımlarının etkin ve verimli sonuçlar üretebilmesini etkileyebilecektir.

2015 ve 2016 yıllarında yanıt alınan başlıklardan bir tanesi de, çevik dönüşümle birlikte gelen "Daha geniş bir organizasyon veya iletişim sorunu" olarak ifade edilmiştir. Değişen şartlara adaptasyonu karşılayabilmek için organizasyonlarda büyüme yeni görev ve sorumluluk alanlarının oluşmasına ihtiyaç duyulabilir. Bu durumda, yeni istihdam sağlanması ile kurum kültürüne yeni giren çalışanların işletme kültürünü, iletişim kanallarını öğrenmesi ve uyum sağlama konusunda bazı problemlerle karşılaşılabilir. Bir diğer yönden, yönetim ve lider desteğinin yetersizliğinden kaynaklanan ve genişleme ile birlikte süreç ve metotların nasıl olacağına dair bilgi ve deneyim eksikliğinin dişavurumu olarak da düşünülebilir.

Çevik dönüşümdeki temel esaslardan birisi, müşteri ile işbirliği içinde çalışarak, hızlı bir şekilde pazara ürünü sunabilmektir. Çevik manifestonun da temel ilkelerinden birisi olan "Müşteri ile beraber çalışmak sözleşmelerden ve anlaşmalardan daha önceliklidir" ilkesi, yasal kurallara ve prosedürlere uyuma zorunluluğu diğer bir ifade ile "Mevzuata uygunluk veya hükümet/devlet sorunu" olarak karşılaşabilmektedir (Agilealliance, 2021). Ancak, bazı durumlarda, müşteri işbirliği tarafında yaşanan iletişim problemleri, "IŞsletme / müşteri / ürün sahibi eksikliği" kaynaklı da olabilmektedir. Çevik dönüşümün benimsenmesinin temel amaçlarından olan ürün ve hizmetlerin zamanında ve doğru kalitede pazara ulaşması için müşteri-işletme etkileşiminin en üst seviyede olması majör faktörlerden birisi olarak da ifade edilebilir. Son yıllarda, popülerliği ve uygulanma alanı artan yüksek müşteri işbirliği ve açık inovasyon kavramları yine bu yanıt çerçevesinde değerlendirilebilir. 
"Geleneksel geliştirme yöntemlerinin yaygınlı̆̆l”; ürün/süreç geliştirme sırasında kullanılan metot ve yöntemin geleneksel olmasının getirmiş olduğu alışkanlıklar ve yerleşik metodolojinin yöneticiler tarafından uygulanma isteği olarak ifade edilebilir. Geleneksel süreçlerde organizasyondaki değişime olan direnç ve çevik yönetim düşüncesinin yeterince benimsenememenin etkileri ile çevik yönetim ile ilgili bilgi ve deneyim eksikliği kaynaklı, eski çalışma şekline yoğun bir tutum ile bağlanma sonucu şeklinde yorumlanabilir. Örneğin, yazılım ürünü geliştirmede geleneksel kültür, "emir-kontrol" (command-control) iken çevik yaklaşımda kültür, "liderlikişbirliği” (leadership-collobration) kullanılmaktadır (Javanmard ve Alian, 2015:1393). Bu durumun bir tezahürü olarak, bazı yöneticiler çevik yönetimde var olan şeffaflık, işbirliği ve katılımcı kültürü, otoritelerinin sarsılması olarak değerlendirebilmekte veya alışmış oldukları iş yapma biçimlerinden ayrılmak istememe tutumunu sergileyebilmektedir.

Çevik yönetim yaklaşımında, bireysel yetkinliklerle birlikte birbirine destek olan takım çalışma kültürünü içermektedir. Müşteri taleplerini, ürün üretim süreçlerinin pazarın ihtiyacına uygun bir şekilde hızlı bir reaksiyon ile karşılık verebilmek için takım içerisinde, görev, sorumluluk ve performans/başarı kriterlerinin tanımlı ve belirli, şeffaf bir ile iletişim ile süreçlerin yönetilmesi gerekmektedir. Bu süreçte, çevik felsefenin kavranmasında yetersizlikler ve eksiklikler olursa, katılımcıların yanıtları arasında bulunan "Minimum işbirliği ve bilgi paylaşımı" , "Parçalı takımlar ve proje ile ilgili veriler / ölçümler", "Ekipler arasında tutarsız süreçler ve uygulamalar" şeklinde sonuçlanabilir. Çevik yönetimin, uygulama alanlarının gelişmekte olduğu, deneyim ve bilgi birikimin sınırlı olmasının da etkileri, çevik yönetim sürecinde darboğazlar oluşmasına sebep olabileceği düşünülmektedir.

Şirketlerin iç ve dış çevresindeki durum ve koşullardaki değişim rüzgârı, farklılaşan müşteri/tüketici beklentileri ile birleşmekte ve organizasyonları sürekli bir değişime uyum sağlamaya itmekte, bu değişim süreci ile örgütsel yenilenme ve gelişme sağlanabilmekte ve organizasyon önemli kazançlar elde edebilmekte olup aksi takdirde iş süreçlerinde organizasyonu krize sürükleyebilmektedir (Çiçeklioğlu, 2020:1).

"Değişime karşı genel organizasyon direnci” y1llar içerisinde artma eğiliminde olduğu görünmektedir. Bunun başlıca sebebi, üst yönetim/yöneticiler kararının dönüşüm sürecinin bütün boyutlarının işgörenlere yeterince paylaşılmaması ile çalışanlar tarafından istenilen seviyede içselleştirmemeye sebep olabileceği düşünülmektedir. Genelde insanların bilinmeze olan çekimser tutumu ve direniş göstermesi, buna mukabil konfor alanını terk etmeme güdüsü ile birleştiğinde organizasyon genelinde bir değişime karşı direnç davranışının temelini oluşturabilir. Değişime karşı olan direnç temelde, dönüşüm sürecinin her yönüyle paylaşımı ve işgörenlerin zihinlerindeki olumsuz düşünceler olup, olumsuzluğu bertaraf edebilecek tatminkâr cevap alınması sağlanarak olumsuz etki minimum seviyelere indirilebilir. Yukarıdaki ifade edilen her bir ana başlık esasen değişime karşı olan direnci doğrudan ve dolaylı olarak artmasına sebep olan faktörler olarak da değerlendirilebilir.

"Değişime karşı genel organizasyon direnci”nin yıllara göre artan bir eğilimde olmasının sebeplerinden birisi, çevik dönüşümü benimsemek isteyen takımların, örgütlerin tercihten çok zorunluluk altında da kalmaları düşünülebilir. Ayrıca, 2015 yılı sonrası farklı bölge ve kültürlerden yeni katılımcıların artmasının da organizasyon direncindeki görece artışın sebeplerinden olabileceği düşünülmektedir.

\section{3. Çevikliği Benimseme Nedenleri}

Organizasyonların içinde bulunduğu rekabet koşullarına en yüksek seviyede adapte olabilmek için örgütün iç ve dış dünyasında gerçekleşen etken faktörleri yakından takip ederler. Günümüz iş dünyasında, organizasyonların varlığını idame ettirebilmek ve sürdürülebilir büyümeyi gerçekleştirebilmek için anahtar noktayı, müşteri/tüketiciyi doğru okumak ve pazara doğru zamanda (genelde en hızlı şekilde) ürün/hizmet sunumunu gerçekleştirmek olarak tanımlamak mümkündür. Diğer bir ifade ile günümüzde dış dünyadaki değişimi takip etmek ve bu değişime ayak uydurmak, daha fazla kâr veya ticari fayda sağlama amaçlı kurumsal bir tercihten ziyade, yoğun rekabet ortamına uyum zorunluluğundur. 
Tablo 3. Çevikliği Benimseme Nedenleri

\begin{tabular}{|c|c|c|c|c|c|c|}
\hline Çevikliği Benimseme Nedenleri & 2015 & 2016 & 2017 & 2018 & 2019 & 2020 \\
\hline Yazılım / ürün teslimatını hızlandırmak & $59 \%$ & $62 \%$ & $69 \%$ & $75 \%$ & $74 \%$ & $71 \%$ \\
\hline Değişen öncelikleri yönetme becerisini geliştirmek & $56 \%$ & $56 \%$ & $61 \%$ & $64 \%$ & $62 \%$ & $63 \%$ \\
\hline Üretkenliği artırmak & $53 \%$ & $55 \%$ & $53 \%$ & $55 \%$ & $51 \%$ & $51 \%$ \\
\hline İş / BT uyumunu iyileştirmek & $40 \%$ & $44 \%$ & $42 \%$ & $49 \%$ & $50 \%$ & $47 \%$ \\
\hline Yazılım kalitesini artırmak & $46 \%$ & $47 \%$ & $43 \%$ & $46 \%$ & $43 \%$ & $42 \%$ \\
\hline Proje riskini azaltmak & $38 \%$ & $40 \%$ & $37 \%$ & $37 \%$ & $28 \%$ & $37 \%$ \\
\hline Proje görünürlüğünü iyileştirmek & $40 \%$ & $40 \%$ & $43 \%$ & $42 \%$ & $42 \%$ & $36 \%$ \\
\hline Takım moralini artırmak & $26 \%$ & $29 \%$ & $31 \%$ & $28 \%$ & $34 \%$ & $31 \%$ \\
\hline Proje maliyetini azaltmak & $23 \%$ & $23 \%$ & $18 \%$ & $24 \%$ & $41 \%$ & $26 \%$ \\
\hline Mühendislik disiplinini geliştirmek & $25 \%$ & $24 \%$ & $21 \%$ & $25 \%$ & $21 \%$ & $23 \%$ \\
\hline Dağıtılmış ekipleri daha iyi yönetim & $20 \%$ & $21 \%$ & $20 \%$ & $17 \%$ & $19 \%$ & $21 \%$ \\
\hline Yazılım sürdürülebilirliğini artırmak & $22 \%$ & $22 \%$ & $18 \%$ & $18 \%$ & $23 \%$ & $18 \%$ \\
\hline Teslimat öngörülebilirliğini geliştirmek & $44 \%$ & $44 \%$ & $30 \%$ & $46 \%$ & $43 \%$ & $39 \%$ \\
\hline
\end{tabular}

Kaynak: Stateofagile, 2020.

Organizasyonlar sahip olduğu kaynaklardan etkin ve verimli süreç yönetimleri ile en üst düzeyde faydalanmay1 amaçlarlar. İktisadi bir ifadeyle, her talebin kendi arzını oluşturduğu günümüzde, arzı /üretimi meydana getiren işletmelerin ve kurumların sahip oldukları altyapı, kapasite ve kaynakların verimli kullanıldığı ölçüde pazar taleplerini karşılayabilirler. Bu sebeple, süreç yönetimlerini değişen ihtiyaçlara göre yeniden kurgulayarak maddi kaynakların doğru alanlara tahsisi ve insan kaynaklarının pazar ihtiyacına karşılık verebilecek yetkinlikte hazırlanması, organizasyonların müşteri odaklı yönetim ve sürdürülebilirlik bağlamındaki değişimlerinin önemli birer parçası olacaktır.

Organizasyonların değişim süreçlerindeki öncelikler, farklılaşan koşullara ve sahip olduğu kaynak ve niteliklere göre değişkenlik gösterebilir. Yı1lık Çevik Durum raporunun incelenmesinin bu bölümünde, "Çevikliği Benimseme Nedenleri” katılımcılara sorulmuş ve birden fazla yanıt alınabilir şekilde görüşler alınmıştır. Aşağıda detayları üzerinde durulacak yanıtların sahip olduğu değerlerdeki dalgalanmalar, yıllar içerisinde bazı önceliklerin değiştiğine ve farklılaştığına dikkat çekmektedir.

Grafik 3. Çevikliği Benimseme Nedenleri

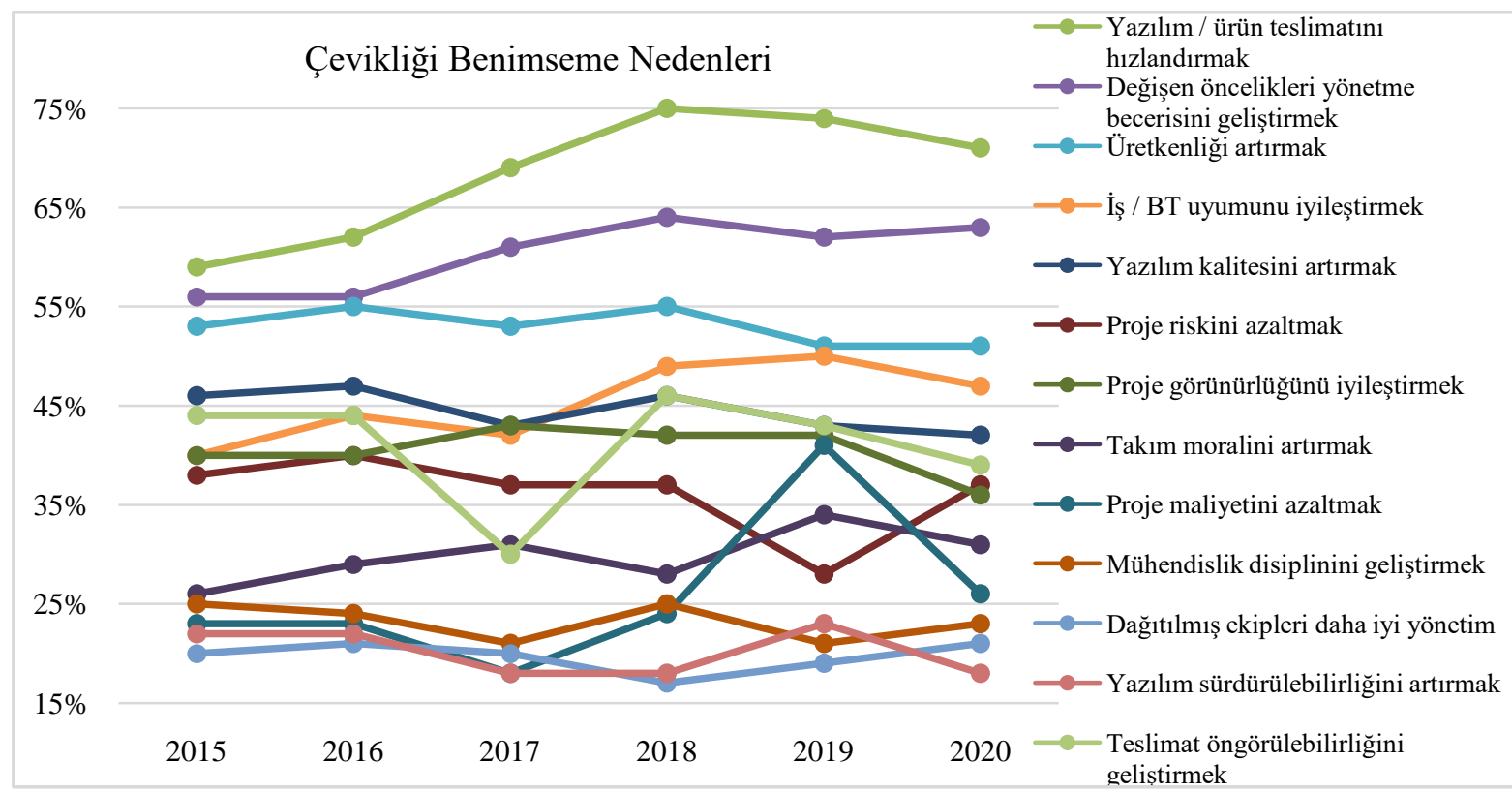

Kaynak: Stateofagile, 2020.

"Çevikliği Benimseme Nedenleri" sorusuna verilen yanıtlarda, en üst seviyede görüş bildirilen nedeni, "Ürün teslimatını hızlandırmak" olarak paylaşılmışıı. Üretim teknoloji ve altyapısının geçmiş dönemlere kıyasla kolay temin edilebilir yapısı, işletmeler tarafından ürünü niceliksel olarak var edebilmeyi sağlayabilmiştir. 
Günümüzde niş alanlar olmadığı sürece, şirketlerin "bir ürünü üretebilme" becerisi, sürdürülebilirlik bağlamında yetersiz kalmaktadır. Buna bağlı olarak, kalite, hız, maliyet avantajı, müşteri deneyimi vb. alanlarda da değer yaratabilecek farklılığ da temin etme zorunluğu bulunmaktadır.

Üretebilme becerisini, "hız" ile birleştirdiğimiz zaman, organizasyonun tedarik, inovasyon, üretim, insan kaynakları, dijital altyapı, nakit akım yönetimi şirketin ana ve destek faaliyetlerinin tamamının müşteri nezdinde değer oluşturabilecek bir sürece evirilmesi gerekmektedir. Bu değişimle birlikte, örgütsel değişime direnç, lider ve üst yönetim desteği, bilgi ve tecrübe konusundaki eksikler, değişim kaynaklı belirsizliğin oluşturabileceği motivasyon kaybı ve gelecek kaygısı gibi organizasyonel dönüşüm sürecinde karşılaşılabilecek çalışan tutum ve davranış temelli etken faktörlerin de ayrıca yönetilmesi gerekmektedir.

Katılımcıların, çevik dönüşümün temel çıktılarından olan “Ürün teslimatını hızlandırmak" ve "Değişen öncelikleri yönetme becerisini geliştirmek" yanıtlarının yıllar içerisinde artan yüzdelerle devam ettirmesi ve diğer majör etken faktörlerden farkı açması, pazar ve müşterilerin talep ve beklentilerinin zaman içerisindeki farklılaşma düzeyine ve talep karşılama beklentisinin sürece ne derece kısaldığına 1şık tutmaktadır. Bu durum, özellikle sosyal medya araçları ile tüm dünyadaki insanların birbiri ile etkileşim kurabildiği ortamlar ve popüler kültür etkisi ile tüketim alışkanlıklarının hızla değiştiği, çeşitlilik kazandığı ve tüketicilerin ivedi şekilde temin etmek istediği bir pazar ortamının oluşmasına zemin oluşturmuştur. Bir diğer ifade ile 2015 yılı sonrası tüm dünyadaki sosyal medya kullanım oranın ivmelenerek artması, çevik yönetimden beklenen hız ve uyum yetkinliğinin ve faydanın da artması ile doğru orantılı olarak arttığı sonucuna ulaşılabilir. Bu verilerin Covid-19 öncesi dönemi nitelediği dikkate alındığında bazı yanıtların pandemi süreci sonrası değişkenlik gösterebileceği düşünülebilir. Örneğin, pandemi süresince "evde kal" uygulamalarının artması ile birlikte, geleneksel satış, pazarlama kanallarının yoğunlukla yerini online alanlara bırakması, lokal bir çok işletmenin ulusal ve küresel pazarlarda etkinliğini artırabilecek fırsatı daha fazla bulabilmesi ile organizasyonların çevik dönüşüme olan ihtiyacını perçinlediği düşünülmektedir.

"Işsletme/İş - BT uyumunu iyileştirmek" çevik yönetim sürecinden beklenen önemli yanıtlardandır. Ürünü pazara doğru zamanda temin edebilmek için sürecin, hammadde satınalma planından, nihai ürünün müşteriye ulaşması ve satış sonrası destek süreçlerinin tamamı müşteri deneyiminin bir parçasıdır ve bu süreçlerin her biri kendi içerisinde alt sistemler, etkileşimler ve entegrasyonlar içermektedir. Dijital dönüşümler genelde karar alma sürecini kolaylaştıran, toplam maliyeti minimize etmeye çalışan, angarya iş süreçlerini ortadan kaldıran, hareket sayısını azaltarak zaman kazandıran süreçlerdir. Dijital dönüşümün bu yapısı ve katkıları sebebiyle de çevik yaklaşım metotlarının ayrılmaz bir parçası olmaktadır.

Pandemi dönemi sonrası dijital dönüşümün gelişmesine paralel olarak, uzaktan çalışma kararlarının alınmasının artmas1 ile sonuçlanabilecektir. $\mathrm{Bu}$ yeni dönemin, değişen tüketici portföyü ile birlikte çevik dönüşüm beklentilerini ve önceliklerini etkileyebileceği düşünülmektedir. Yeni dönemde, "Çevik dönüşümü benimseme nedenleri" başlığı altındaki "İ̧sletme/İ̧s - BT uyumunu iyileştirmek" başlı̆̆ daha yüksek oranlarda tercih edileceği öngörülmektedir. Bu durum, işletmelerin gelecek dönemdeki dijital altyapıyı güçlendirecek ve kurum içerisindeki çalışanların iş yapma biçimlerindeki yaklaşımlarını da farklılaştırabilecek, işgücü profilinde daha genç, teknoloji kullanımına yatkın ve öğrenmeye açık bireylerin öncelikli tercih edilmesi gibi organizasyonların yönetim süreçlerini de derinden etkileyebilecek bir dönüşümün içinde olacağ tahmin edilmektedir.

"Üretkenliği artırmak" kaynakların verimli kullanılmasına dair en temel hedef ve referanslardandır. Tüketici tercih ve beklentilerinin değişmesi; VUCA döneminin etkisi ile birlikte talepleri tahmin edebilmenin zorlukları ile birleşmiştir. Diğer taraftan, tedarik ve stok maliyetleri yükselmiş, nakit akım yönetiminde olabilecek belirsizlik ve riskler, şirket yönetimi zorlayan argüman olarak daha belirgin hale gelmiştir. Hammadde ve bitmiş ürün stoklamanın belirsizlik ortamında getireceği mali külfet, gelecek kararlarını da doğrudan etkileyebilmektedir. Siparişe göre üretim anlayışının çevik yaklaşım ile birleşmesinde, sürekli iyileştirme (Kaizen) ve yalın üretim anlayışını güçlendiren, hazırlık sürelerini minimize edecek ve müşteri nezdinde değer oluşturmayan süreçlerin eliminasyonu sağlayacak esnek üretim kabiliyeti ve örgütsel öğrenme sayesinde sürekli kendisine yeni ödevler çıkaran takım ruhu ile çalışma hedefi çevik yönetimin benimsenme nedenleri arasında gösterilebilir. Bu yapısal dönüşüm anlayışının benimsenmesi süresince, iş yapma biçimlerindeki farklılaşmalar majör iş tutumlarını etkileyebilecek alanlar olup, örgütsel davranışlar bağlamında da takip edilmedir.

"Takım moralini artırmak" yıllar içerisinde minör artışlarla yanıt alan bir diğer "Çevikliği benimseme nedeni" olarak ifade edilmiştir. Yönetim sürecinde, çalışan motivasyonun artmasının iş performansı ve verimlilik arasında anlamlı ve pozitif ilişki bir çok akademik çalışmada belirlenmiştir (Akçay, 2019:135; Yılmaz, 2016:72; Yapar, 2015:205). Bu durumun bir dişa vurumu olarak, çevik yönetimi benimseyenler, mutlu çalışan-başarılı şirket anlayışı 1şığında takım moral/motivasyonu artıracak çalışmalar yapmaktadır. Bu noktada, yıllar geçtikçe 
takım yapısının gençleşiyor olması ve $Y$ ve $Z$ kuşağının üretim ve yönetim süreçlerinde daha fazla sorumluluk sahibi olmaya başlaması ile bu kuşakların vizyon, hayat amacı, beklenti ve değerlerini anlayarak organizasyona yüksek katkılar sunan başarılı takımların oluşturulabileceği düşünülmektedir.

"Çevikliği benimseme nedenleri" arasında, "Yazılım/ürün kalitesini artırmak" ifadesi genelde minör kayıplarla yatay bir seyirde devam etmektedir. Bilindiği üzere ürün özelindeki kalite kavramı, temel iş süreçlerindeki maliyet, zaman, operasyon gibi dinamiklerle ilişki içerisindedir. Bu ilişki ürün üretim süreci ve müşteriye teslim sürecini artıracak ek prosedürel ve denetim süreçlerini beraberinde getirmektedir. Grafik 3. üzerine yapılan okumalardan birisi de, yıllar içerisindeki yüksek ivme ile artan "Ürün teslimatını hızlandırmak" yanıtına kıyasla, ürün kalitesini artmanın yatay bir görünüm çizmesi, müşterinin talep ettiği standart kaliteyi, en hızlı zamanda müşteriye sunmak, incelenen dönemin katma değerli süreci olarak ifade edilebilir.

\section{4. Çevik Dönüşümde Başarı Kriterleri}

Organizasyonlar sürdürülebilirliklerini sağlamak üzere oluşturdukları stratejik hedeflere bağlı olarak operasyonel süreçleri de kapsayan performans ölçütleri ve başarı kriterleri belirlerler. Başarı kriterleri hangi iş süreçlerinin daha önemli olduğunu da niteler özellikte olup, kök neden analizleri ile katma değer yaratmayan iş süreçlerinin de ortadan kaldırılmasına yardımcı olan bir araçtır.

Çevik yönetim yaklaşımını benimsemiş şirketlerdeki "Başarı nasıl ölçülür?” sorusuna verilen yanıtlar; çevik dönüşüm süresince hangi hedeflerin başarıya ulaşılmasının önceliklendirildiği ve çevik dönüşümden beklentilerin ne olduğunu anlamamıza katkı sunacaktır. Katılımcılara yukarıdaki başlıklarda olduğu gibi birden fazla başarı göstergesini yanıtlama seçeneği verilmiştir.

Başarı göstergesinin 2015-2020 yılları arasında en yüksek ivme ile kabul gören ölçüt "Müşteri/kullanıcı memnuniyeti" olmuştur. Müşteri; kar amacı güden kurumların varlıklarını devam ettirmek ve sürdürülebilir bir büyümenin yegâne değeridir. Müşteri memnuniyeti, bir ürünün aynı müşteri tarafından yeniden alınmasının teminidir, kurumların gelecek beklentilerini realize edebilme çabasının somut göstergesidir. Rekabetin en üst seviyede yaşandığı günümüzde yeni bir müssteriyi bulma zorluğu ve müşteri kaybetmeden kazan kazan kültürü içerisinde şirkete olan bağlılığını devam ettirebilme çabası şirketleri olabildiğince zorlamaktadır. Bu zorluğun üstesinden gelebilmek için şirketler, farklı yönetsel yaklaşımlar ve iş modelleri ile yenilikçi ürün ve hizmet sunarak müşteri memnuniyetini maksimize etme gayreti içerisindedirler.

Çevik dönüşümlerdeki en fazla tercih gören başarı göstergelerinden ikincisi, iş değeridir. İş değeri; şirketin sahip olduğu entelektüel sermayesi, iş modeli, müşteri, tedarikçi, çalışan, topluma sunduğu değerlerin tamamını kapsamaktadır. İş değeri, sürdürülebilirlik düşüncesinin ve uygulamalarının merkezinde bulunduğunu ifade edebiliriz. Çevik dönüşümle, doğru liderlerle, doğru takım kurma, takımlar arasındaki formal ve informal iletişimlerini tesis etme, müşteri odaklı organizasyon kültürü oluşturabilmek yeni katma değer oluşturmanın anahtarı olabilmektedir. Bu dönüşüm sayesinde, şirketler sahip oldukları maddi ve maddi olmayan bütün kaynaklar etkin ve verimli yönetimini sağlayabilecek ve geleceğe daha emin adımlarla kendisini taşıma imkânı bulabilecektir.

Tablo 4. Başarı Nasıl Ölçülür (Başarı Göstergesi) Nedir?

\begin{tabular}{|c|c|c|c|c|c|c|}
\hline Başarı nasıl ölçülür... (çevik dönüşümlerle) & $\mathbf{2 0 1 5}$ & $\mathbf{2 0 1 6}$ & $\mathbf{2 0 1 7}$ & $\mathbf{2 0 1 8}$ & $\mathbf{2 0 1 9}$ & $\mathbf{2 0 2 0}$ \\
\hline Müşteri / kullanıcı memnuniyeti & $44 \%$ & $46 \%$ & $44 \%$ & $57 \%$ & $52 \%$ & $58 \%$ \\
\hline İş değeri & $44 \%$ & $46 \%$ & $46 \%$ & $53 \%$ & $41 \%$ & $54 \%$ \\
\hline Zamanında teslimat & $58 \%$ & $58 \%$ & $53 \%$ & $55 \%$ & $48 \%$ & $48 \%$ \\
\hline Ulaşılan iş hedefleri & & & & & $44 \%$ \\
\hline Kalite / Ürün kalitesi & $48 \%$ & $48 \%$ & $42 \%$ & $47 \%$ & $38 \%$ & $45 \%$ \\
\hline Üretkenlik & $29 \%$ & $31 \%$ & $25 \%$ & $31 \%$ & $33 \%$ & $40 \%$ \\
\hline Örgütsel kültür / moral & & & & & $37 \%$ \\
\hline Tahmin edilebilirlik & $25 \%$ & $26 \%$ & $23 \%$ & $29 \%$ & $30 \%$ & $33 \%$ \\
\hline Süreç geliştirme & $23 \%$ & $24 \%$ & $21 \%$ & $25 \%$ & $25 \%$ & $35 \%$ \\
\hline Proje görünürlüğü & $30 \%$ & $30 \%$ & $25 \%$ & $26 \%$ & $27 \%$ & $29 \%$ \\
\hline Ürün kapsamı (özellikler, gereksinimler) & $39 \%$ & $36 \%$ & $40 \%$ & $20 \%$ & $12 \%$ & $15 \%$ \\
\hline Bilmiyorum & $11 \%$ & $11 \%$ & $11 \%$ & $11 \%$ & & 25 \\
\hline
\end{tabular}

Kaynak: Stateofagile, 2020. 
Grafik 4. Başarı Nasıl Ölçülür (Başarı Göstergesi) Nedir?

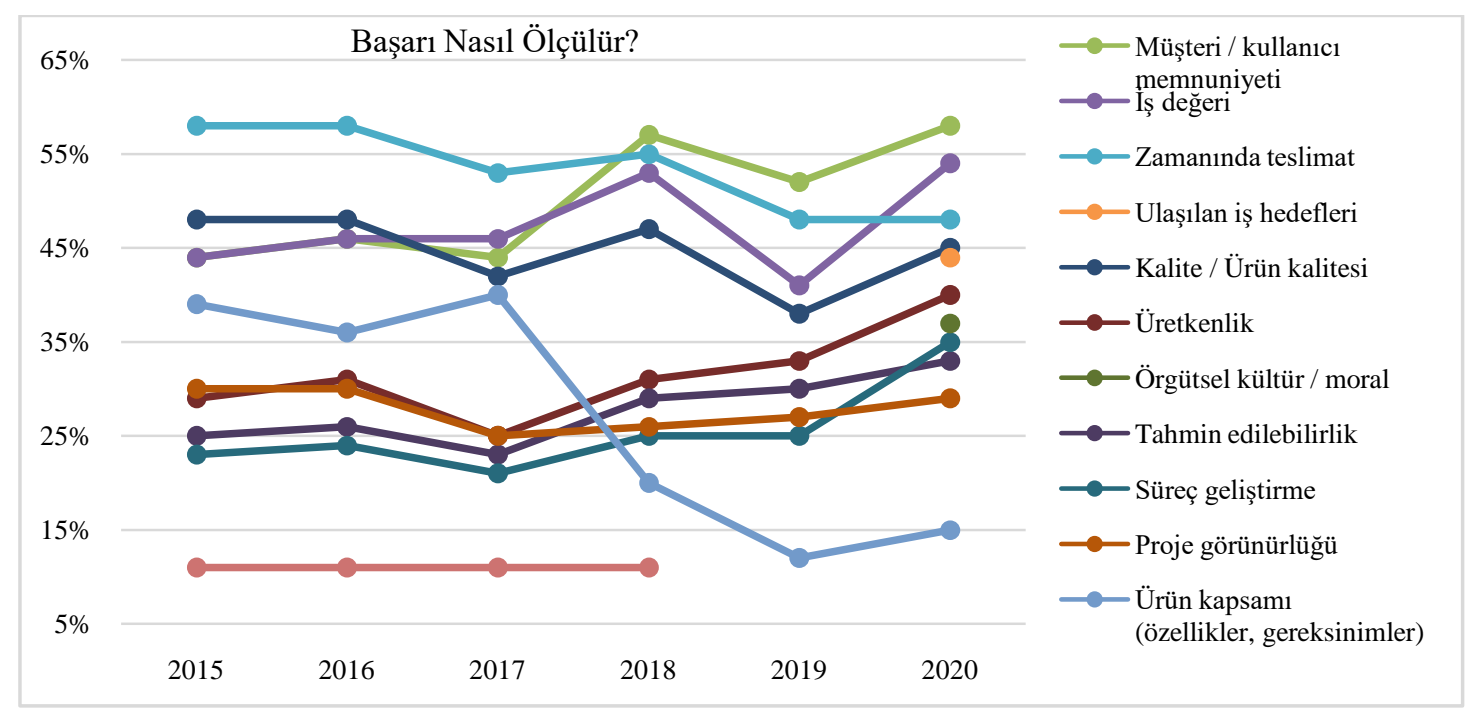

Kaynak: Stateofagile, 2020

Işs değeri, müşteri memnuniyetini besleyen bir faktör olarak da görülebilir. Artık müşteri /tüketicilerin birçoğu, ürün veya hizmet alırken, ürünün markası, işlevi, fiyatı, kalitesi ile birlikte çevreye, topluma, ekonomiye sunduğu değerleri de göz önüne almaktadır. Ayrıca, yüksek iş değeri şirketlerin marka değerini de olumlu etkileyerek, bu etki gücü gelecekte organizasyonların ihtiyacı olan insan kaynaklarının, havuzlardan yüksek potansiyelli, alanında uzman, yetenekli çalışanların organizasyona dâhil olmasını kolaylaştıracaktır.

Covid-19 ile birlikte gelen bireysel, toplumsal ve idari alanlardaki güncel bazı yeni sorumlulukların paydaş kültürünün genişlemesine katkı sunarak şirketlerin değer kavramını yeniden tanımlamasına ve genişletmesini de beraberinde getireceği düşünülmektedir. Bu yaklaşımla, iş değeri kavramının tanımsal kapsamın genişlemesi ile ürün ve/veya hizmetin; hammadde tedarik planından, nihai kullanıcıya ulaşıncaya kadarki zincirde birey, sosyaltoplumsal değerler ve çevre üzerinde bıraktı̆̆ izler, gelecek değer anlayışının ve başarı göstergesinin temel referanslarını oluşturmada güçlenerek devam edecektir.

"Zamanında teslimat" başarı göstergeleri arasında yüksek yanıt yüzdesine sahip performans ölçütlerinden birisidir. Zamanında teslimat, çevik yönetimin temel beklenti ve argümanlarından birisidir. Gelecek dönemde de ilk sıralardaki yerini koruyacağı öngörülmektedir. "Zamanında teslimat" yanıtı 2015 yılından 2020 yılına kadar minör negatif bir eğilim grafiği göstermiştir. Bu süre zarfinda, negatif eğimin sebebi; yoğun rekabet ve çevresel koşullar içerisinde tüketici talep ve beklentilerinin değişmesi ile birlikte, müşteri memnuniyetini ve iş deneyimini daha yukarı seviyelere çıkarmak için iş süreçlerine başta müşteri olmak üzere diğer paydaşların da dâhil edilmesi ile yeni yöntem ve uygulamalar ile başarılı sonuçlar üretmek "zaman" kısıtından kısmi ödünler vererek mümkün olabildiği düşünülmektedir. Nitekim 6 yıllık dönemdeki "Başarl göstergesi nedir?" grafiğinde (Grafik 4.) "Müssteri memnuniyeti" ve "İş değeri" artan ivmede iken "Zamaninda Teslimat" azalan bir eğim göstermesinin, "zaman" konusunda müşterinin bilgi ve onayı ile örtüştüğü sonucunu çıkarmak mümkün olabilecektir.

“Ürün kalitesi” yıllar içerisinde genel olarak yatay bir görünüme sahip özelliktedir. Bazı dönemlerde negatif eğimli bir görünümde olmasının sebebinin müşteri deneyimini artırmak için müşteri nezdinde farkındalık ve değer oluşturmayan süreçlerin ortadan kaldırılmasından kaynaklı standart kalite kavramındaki anlayışın ve kabulün değişmesi olabilir. Ek olarak, sürdürülebilir bir ilerleme sağlanabilmesi için müşteri/tüketiciye sunulan ürünlerin kalite özelliklerinin, nihai kullanıcılar tarafından kabul edilen fiyat-kalite-zaman parametrelerine uygun bir şekilde olması gelecek yıllarda da devam edeceği beklenmektedir.

Çevikliğin var oluş felsefesinin temel özelliklerinden birisi bilindiği üzere müşteri odaklı değişen önceliklere uyum gösterebilmedir. Özellikle, VUCA ortamının da gelecek bilinmezliği müşteriden gelen gerçek siparişlere hızlı bir şekilde yanıt verme becerisi, yeni ve tekrar siparişlerin öncülü niteliğindedir. Organizasyonlar müşteri talebini hızlı karşılayabilmek için iş süreçlerinde planlı / plansız üretim değişikliklerini daha fazla yapma zorunda kalabilmekte, kalite kayıpları artabilmekte ve bu durumun etkisi ile etkin kapasite kullanımda noksanlıklar ve üretkenlikte kayıplarla karşılaşılabilmektedir. Müşteri memnuniyetini yüksek seviyelere 
çıkarabilmenin operasyonel süreçlerdeki yan etkisini (kalite, zaman, maliyet vb.) minimize etmek ve birim zamanda daha fazla üretebilmek için iş süreçlerinde "Üretkenlik" takibi çok büyük öneme sahiptir.

Şirketlerin dış ve iç çevresinden gelen değişim baskısı ve rekabetin yıllar içerisinde daha zorlu hale gelmesi, şirketlerin içe dönük proseslerinde katma değer oluşturmayan işlemlerin ortadan kaldırılmasıyla da üretkenliklerin artması hedeflemektedir. Küreselleşmenin de etkisi ile ticaretin tüm süreçlerinde var olan rekabet, şirketlerin fiyat artırma esnekliğini elinden alarak, şirketleri piyasa fiyatı üzerinden ürünlerin satışına zorlamaktadır. Bu sebeple, büyümenin temel referansı olan kârı elde etme amacıyla, şirketin üretkenliğe ve birim zamandaki operasyonel verimliliğine daha fazla dikkat etmesi ve öncelikli konular arasına alması çevik bir süreç dinamiğidir.

“Örgütsel kültür / moral” başarı göstergeleri arasında ilk olarak 2020 yılı içerisinde değerlendirmeye alınmıştır. Çevik bir takımın yetenekli ve yetkin bireylerden oluşmasıyla birlikte, ekip içerisindeki birbirlerine uyum, bağl1lık, motivasyon, özerklik, destek görme, takdir etme, ödüllendirme gibi özellikleri içerisinde barından bir örgüt kültürü içerisinde olması çalışanların birey olarak odak noktalarını işlerine yoğunlaştıracağı bir ortamı hazırlayacaktır. Hawthorne deneylerinden (1927-1932) bugüne, bireylerin iş performansını etkileyebilecek psikolojik faktörlerin varlığı tartışılmaz bir gerçek olmakla birlikte, çevik yaklaşımın başarılı işlemesi için gerekli örgütsel yapı ve kültürün katılımcılar tarafından önemli bir performans göstergesi olarak ele alınması dikkate değerdir. 2020 yılı itibari ile tüm dünyayı etkileyen Covid-19 virüsü, uzaktan çalışma zorunluluğuna maruz kalan işgörenlerin motivasyon süreçlerinin de birey odaklı perspektifle yeniden ele alınması gerektiğini de ortaya koymaktadır.

Uzaktan çalışma kültürünün teknoloji ve iletişim imkânlarının daha da yaygınlaşmasına paralel bir şekilde, çalışma hayatında daha fazla tercih edilmesi ile birlikte, örgütsel bağl1lık, örgütsel vatandaşlık, iş tatmini kavramlarının kapsamı değişebilecektir. Yakın gelecekteki iş yapma biçimlerindeki köklü değişimin etkisi ile doğru yetkinliğe sahip çalı̧̧an profilini keşfetmek ve sürdürülebilir insan kaynakları modeli içerisinde devamlılığını sağlamak organizasyonları geçmişe kıyasla daha da zorlayacaktır. Yine gelecek dönemlerde, "birey"i merkeze alan motivasyon ve örgüt kültürünün oluşabileceğini ve bu sorumluluğun sadece insan kaynaklarının değil, takımı yöneten liderlerin de başarı göstergesi olarak kabul edeceği bir çalışma düzenini beraberinde getirebilecektir.

İş dünyasının içerisinde bulunduğu VUCA dünyası, gelecek bilinmezliğine karşı organizasyonları farklı yöntem ve teknik geliştirmeye zorlamaktadır. Belirsizliğin etkisini minimize etmenin ve doğru kaynak kullanımın sağlanması için geleceğe dönük "Tahmin edilebilirlik" başarı kriterleri arasında yerini aldığı düşünülmektedir. Özellikle, geçmişten günümüze büyük veri (big data) kullanımının artması ile bir çok veri ve bilgiye kolay ulaşılabilir olması, istatistiksel yöntemlerle geleceği tahmin etmede bir başarı faktörü olarak tahmin edilebilirliğin önemini artırmaktadır. Ancak, 2020 yılı pandemi dönemi ve sonrası ekonomik ve ticari hayatın bir kırılma noktasından geçtiğini dikkate aldığımızda, "Tahmin edilebilirlik" gelecek yıllarda yükselen bir eğimle başarı göstergeleri arasında etkinliğini koruyacağı düşünülmektedir.

2000 yılından sonra tüketim alışkanlıklarının hızla değişmesi ve ürün yaşam ömürlerinin çok kısalması ile birlikte, sosyo-ekonomik, finansal, yasal birçok değişkenin etkisi ile değişken, belirsiz ve karmaşık bir ticari ortam söz konusudur. Müşteri/Tüketici memnuniyetini artırmak ve belirsizlik ile başa çıkmak isteyen örgütler, organizasyonun iç süreçlerini daha çevik hale getirebilecek, "Süreç geliştirme" metotları ile üretilen ürün ve hizmetleri nihai kullanıcılara hızlı bir şekilde ulaştırmayı hedeflemektedir.

Dış dünyanın hızla değişmesi ile organizasyonlar, iş süreçlerinde kullanılan birçok geleneksel metodolojiden ziyade daha çevik yöntemlerden faydalanmayı amaçlamaktadır. Değer zinciri analizleri, yalın üretim süreçleri benimsenmesi ve sürekli iyileştirme (Kaizen) kültürünün getirdiği katma değerli geliştirmeler ile müşteri deneyimini yükseltmek ve sadeleşme, maliyetleri azaltma, zaman kazancı ve kaynakların daha etkin kullanılması yeni "Süreç geliştirme"ler ile sağlanabilmektedir.

"Ürün kapsamı" bir ürünün/hizmetin özelliklerini; tasarım, işlev ve bileşen parçalarını ifade eden bir terimdir. "Ürün kapsamı" başarı göstergeleri arasında yıllar içerisinde en alt sıraya gerileyen bir performans faktörü olarak görünmektedir. Temelde bu eğimin negatif yönde olması, standart ve sabit bir ürün veya hizmet sunumundan ziyade, çevik yönetimin müşteri veya kullanıcı ile entegre ürün tasarlama süreci ve tasarım sürecinin taleplere göre farklı özellik taşıması olarak düşünülebilir. Bu sebeple, amaç standart ve stabil olmaktan ziyade dönem ve pazar dinamiklerini dikkate alarak farklı ürün / hizmeti farklı pazarlara sunma imkanı ve esnekliği sağlanabilmektedir. 


\subsection{Katılımcıların Çalıştığı Sektörler}

Çevik yönetim yaklaşımı, yazılım sektöründe başlayıp zaman içerisinde farklı sektörlerde anlam ve boyut kazanan güncel ve gelişim gösteren bir iş yapma kültürüdür. Çevik yönetimi benimseme, yazılım sektöründe başlaması ve güçlenmesinin doğal bir sonucu olarak yaklaşık her 4 çalışandan birisini "teknoloji / yazılım" şirketlerinde çalıştığı gözlemlenmektedir. Özellikle, yazılım ve teknoloji alanın bulunduğu sektör itibari ile dijital tabanlı ürün üretmesi, her geçen gün üretimi etkileyebilecek altyapı, metot, uygulamada yeni özelliklerin gelişmesi, internet ve sosyal medya aracılığı ile ürün ve hizmetin çok hızlı yayılabiliyor olması, organizasyonları sürekli hazır ve nazır olma gerekliliğini beraberinde getirmektedir.

"Finansal hizmetler" alanlarda, özellikle ürün ve hizmet sunumunda dijital altyapının hızla gelişiyor olması ve kullanıcıların her türlü hareketini izleyebiliyor olmanın getirmiş olduğu büyük veri (big data) sayesinde, müşteri memnuniyetini en hızlı şekilde karşılayarak artırabilmek, operasyonel süreçlerini etkin yönetebilmek için çevik yönetimin artan bir ivme ile benimsendiği düşünülmektedir.

"Profesyonel hizmetler" genel olarak, ürün müşteriye ulaştıktan sonra, müşterinin kullanımı sırasında oluşabilen olumsuz bir durum karşısında, ürün/marka sahibinin satış sonrası hizmetler için anlaştığı kurumları temsil etmektedir. Özellikle, müşteri deneyimini ve memnuniyetini yükseltmeyi hedefleyen şirketler, ürün satış sonrası süreçlerini de kendi sorumlulukları altında tutarak ürün marka değerine katkı sağlayacak süreçlere dönüştürmek istemeleri, profesyonel hizmetlerin marka sahibine doğru tersine bir dönüşe sebep olmaktadır. Ayrıca, özellikle dijital ve teknoloji tabanlı ürün/hizmet satışı gerçekleştiren şirketlerin akıllı eskitme kavramı ile bir üst sürüm veya versiyonlu bir ürünü satın almaya zorlayan güncel yaklaşımlar "profesyonel hizmetler" alanındaki iş yapmayı kısıtlayan süreçler olarak düşünülebilir. $\mathrm{Bu}$ durumların bir sonucu olarak, geçmişten günümüze "Profesyonel hizmetler" alanında çevik yönetimi benimsemeye yönelik bir daralma olduğu şeklinde okunabilir. "Sigorta" alanında müşteri deneyimi artıracak, müşteriye ait kullanıma açık her türlü veriyi işleyerek kazankazan ilişkisi içerisinde doğru ürün ve hizmetleri sunabilmek, kaynakları verimli kullanmak için çevik yönetimin benimsenmesi yıllar içerisinde artan bir eğilim çizdiği gözlemlenmektedir.

Tablo 5. Katılımcıların Çalıştı̆̆ Sektörler

\begin{tabular}{|c|c|c|c|c|c|c|}
\hline Katılımcıların çalıştı̆̆ı sektörler & 2015 & 2016 & 2017 & 2018 & 2019 & 2020 \\
\hline Teknoloji / Yazılım (ISV) & $25 \%$ & $26 \%$ & $23 \%$ & $24 \%$ & $25 \%$ & $27 \%$ \\
\hline Finansal hizmetler & $12 \%$ & $14 \%$ & $14 \%$ & $17 \%$ & $19 \%$ & $17 \%$ \\
\hline Profesyonel hizmetler & $11 \%$ & $11 \%$ & $12 \%$ & $9 \%$ & $10 \%$ & $7 \%$ \\
\hline Devlet & $6 \%$ & $6 \%$ & $5 \%$ & $6 \%$ & $6 \%$ & $7 \%$ \\
\hline Sigorta & $3 \%$ & $4 \%$ & $6 \%$ & $7 \%$ & $8 \%$ & $6 \%$ \\
\hline Endüstriyel / İmalat & $4 \%$ & $3 \%$ & $4 \%$ & $4 \%$ & $4 \%$ & $5 \%$ \\
\hline Telekomünikasyon & $4 \%$ & $4 \%$ & $4 \%$ & $4 \%$ & $4 \%$ & $5 \%$ \\
\hline Sağlık ve İlaç & $7 \%$ & $6 \%$ & $6 \%$ & $6 \%$ & $6 \%$ & $4 \%$ \\
\hline Eğitim & & & $3 \%$ & $3 \%$ & $3 \%$ & $4 \%$ \\
\hline Perakende & $4 \%$ & $3 \%$ & $3 \%$ & $3 \%$ & $3 \%$ & $4 \%$ \\
\hline Medya ve Eğlence & $3 \%$ & $3 \%$ & $3 \%$ & $2 \%$ & $1 \%$ & $3 \%$ \\
\hline Ulaşım & $3 \%$ & $2 \%$ & $4 \%$ & $3 \%$ & $3 \%$ & $3 \%$ \\
\hline Enerji & & & & $3 \%$ & $4 \%$ & $2 \%$ \\
\hline Kar Amacı Gütmeyen & & & & $1 \%$ & $1 \%$ & $2 \%$ \\
\hline Kamu Kuruluşları & $1 \%$ & $2 \%$ & $2 \%$ & & & \\
\hline İnternet hizmetleri & $3 \%$ & $3 \%$ & $3 \%$ & & & \\
\hline Tüketici ürünleri & $2 \%$ & $2 \%$ & $2 \%$ & & & \\
\hline Kamu Hizmetleri & $1 \%$ & $1 \%$ & $1 \%$ & & & \\
\hline Diğer & $11 \%$ & $10 \%$ & $8 \%$ & $8 \%$ & $3 \%$ & $4 \%$ \\
\hline
\end{tabular}

Kaynak: Stateofagile, 2020. 
Grafik 5. Katılımcıların Çalıştığı Sektörler

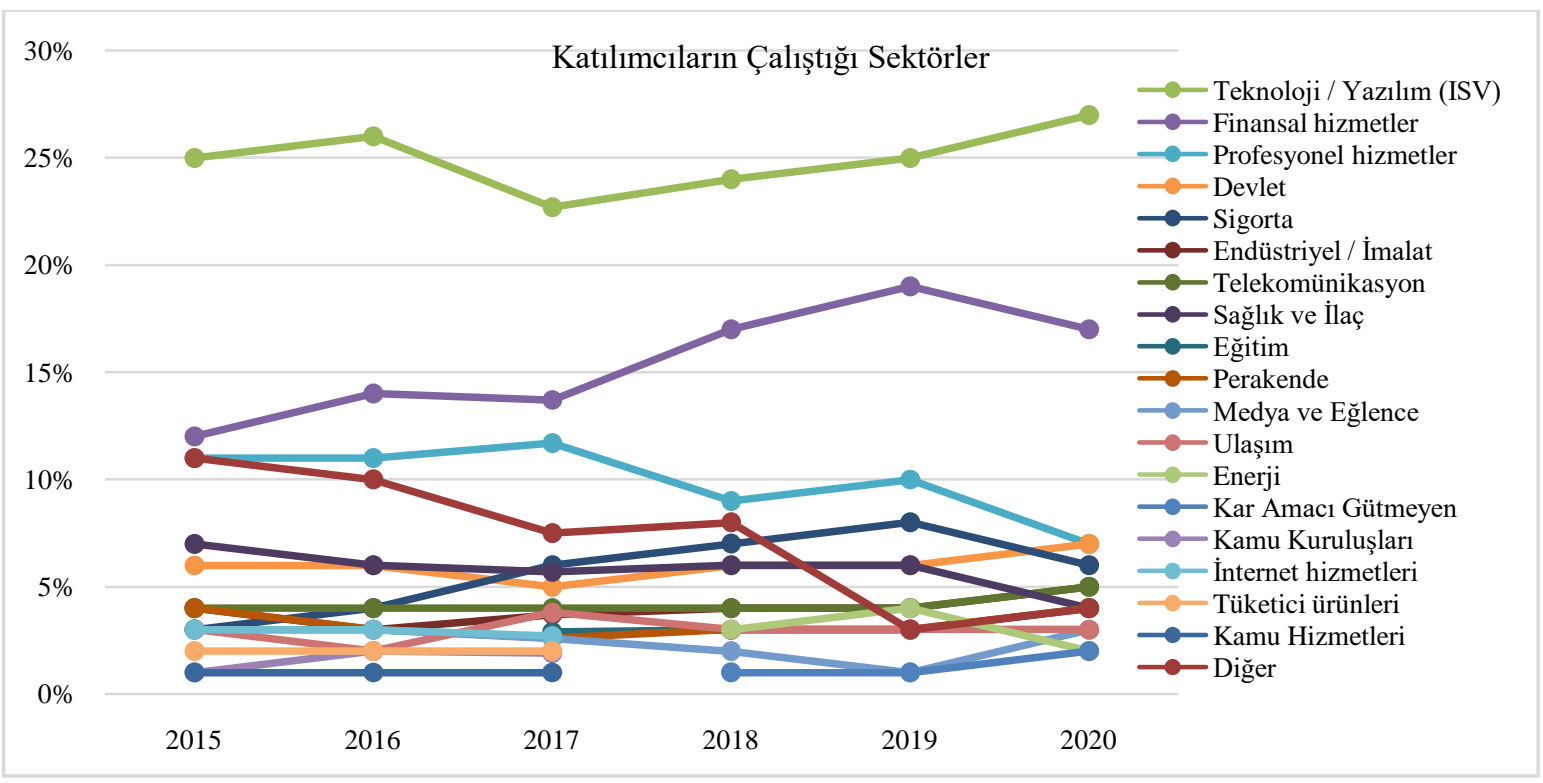

Kaynak: Stateofagile, 2020

“Endüstriyel/İmalat” sektöründe yıllar içerisinde genelde yatay ve 2020'de artan bir trend görünmektedir. Çevik yönetim süreci imalat sektöründe, genel olarak operasyon süreçlerinin gelişmesi için yalın üretim ve kaizen kültüründe ve son dönemlerde artan bir ivme olan açık inovasyon kavramı ile yeni bir ürün üretme sürecinde çevik yönetim anlayışı gelişmektedir. Özellikle, imalat sektöründe var olan müşteri deneyimi sürekli kılmaya çalışan ilişkisel pazarlama yöntemleri ile elde edilen bulgular çevik yönetim sürecinin önemli birer girdisi olarak düşünülebilir. 2020 yılı pandemi dönemi etkisi ile daralan ticari ve ekonomik yapıda müşteri daha kıymetli hale gelmiş, teknoloji ve iletişim araçlarının sunmuş olduğu katkıları, iş ve yönetim süreçlerine daha fazla dâhil ederek imalat sektörünün hemen her fonksiyonunda çevik yaklaşımın artan grafiğinin devam edeceği düşünülmektedir.

"Eğitim" sektörü 2017 y1lı çalışmasında günümüze yatay ve artan bir seyirde varlık göstermiştir. Dijital dünyasının gelişmesi ve genişlemesi ile eğitim araçlarında yaygın bir kullanım sağlamış olup, değişen iş dünyasına adapte olabilecek profili yetiştirebilmek için eğitim alanının çevik yaklaşımı benimsediği düşünülmektedir. Ayrıca, 2020 yılı pandemi döneminde "evde kal" uygulamaları gerek öğrenci gerekse işgören nezdinde ihtiyacı olan eğitim programlarının uzaktan/online araçlarla yapılmasını sağlamıştır. Bu dönemde, uzaktan çalışma kültürünün bir zorunluluğu ile dijital öğrenme, online öğrenme yolları kişisel gelişime oldukça katk1 sunmuştur. Bu sebeple, eğitim kurumlarının geleceğin iş dünyasının ihtiyaçlarını karşılama misyonu için hazırlamış oldukları programlar sayesinde, eğitim kurumlarının diğer sektör ve alanlara çevik yaklaşımı benimsetme noktasında öncül bir rol alacağı da düşünülmektedir.

\section{SONUÇ}

Çevik yönetim yaklaşımı, yazılım sektöründe bir proje geliştirme uygulaması olarak başlamış ve yıllar içerisinde anlam ve kapsamı genişleyerek yönetim uygulamalarına bir felsefe ve anlayış kazandırmıştır. Bu güncel perspektifle, organizasyonların çevik dönüşüm sürecinde karşılaşabilecekleri tüm durumları ortaya koyabilmek ve dönüşüm sürecini daha kolay yönetebilmek için "Yıllık Çevik Durum Raporu" referans kaynak kabul edilmiş ve analiz edilmiştir.

VersionOne tarafından düzenlenen "Ylllık Çevik Durum Raporu"; 2007 yılından günümüze kadar toplam katılımcı sayısı 40 bini aşmış ve dünya genelinde her yıl çevik yönetimi benimseyen uygulayıcıların deneyimlerini kaydetmiş raporlar bütünüdür. "Ylllık Çevik Durum Raporu" 2015 yılından itibaren katılımcılara sorulan soruların kapsamlarının genişlemesi, farklı sektörlerden, daha geniş katılımcıların çevik dönüşüm süreci ve sonrasındaki deneyimleri paylaşı1mıştır. Yönetim alanına genelleme yapabilmek ve kapsayıcı yorumlarda bulunabilmek için 2015-2020 yılları arasında verilen yanıtlar bu çalışmanın veri kaynağını oluşturmuştur. Uygulayıcıların saha tecrübesinden gelen deneyimleri ve 6 yıllık süre zarfinda bu deneyimlerin nasıl farklılaştı̆̆ 
detaylı bir şekilde incelenmiştir. Çalışmanın beslendiği bu raporlar; muhteva eden soru, yanıt ve dönem aralıkları aynı zamanda çalışmanın kısıtları olarak da nitelenebilir.

Önceki bölümlerde çevik yaklaşımın benimsenme nedenleri, dönüşüm sürecindeki zorluklar, çevik yönetimin faydaları ve performans göstergeleri/başarı kriterleri detaylı bir şekilde incelenmiştir. Bu incelemeler sonucu, çevik yönetim anlayışının benimsenmesi ve dönüşüm sürecinde öncelikli olarak dikkat edilmesi gereken noktaların belirlenmesi amaçlanmış, gelecek dönemin iş ve ticaret anlayışlarının ihtiyaçları güncel paradigma değişikliklerin etkisi ile yeniden yorumlanmış ve "Sürdürülebilir" ana başlığı altındaki temel noktalar ile genişletilerek aşağıdaki ilişki modeli oluşturulmuştur. Bu çalışmadaki model önerisi (Tablo 6.), çevik yaklaşım ve dönüşüm sürecini benimsemek isteyen işletmelerin karşılaşabilecekleri majör noktalara dikkat çekmek ve sürecin etkin bir şekilde sonuçlanması için gerekli koşulların tesis edilmesini tavsiye eden bir rehber niteliğinde olduğu düşünülmektedir.

Çalışmada öne sürdüğümüz, çevik dönüşüm modelinin ana amacı sürdürülebilir ve yüksek "Müssteri Deneyimi”" oluşturmaktadır. Şirketlerin gelecek dönemlere sağlıklı bir şekilde devam edebilmesini sağlayan temel noktalar rekabet üstünlüğü, sürdürülebilir kâr ve büyümedir. Sağlıklı büyümenin de ana hattını, şirketlerin sahip olduğu sadık müşteri / tüketici portföyleri oluşturmaktadır. Bu noktadan hareketle, tüketici/müşterinin ihtiyaçlarının doğru tahmin edilmesi, belirlenmesi ve planlanması sürecinden başlayıp, nihai tüketiciye ürün ulaşması ve yeniden satın alma tutumuna girmesini sağlaması için müşteri deneyimini en iyileştirecek yaklaşım ile tüm operasyonel süreçler tasarlanmalı ve yönetilmelidir.

Müşteri deneyimi, tüketicilerin/müşterilerin ihtiyaç, istek ve taleplerine uygun ürünlerin; doğru zaman, doğru miktar, doğru kalite, doğru fiyatla sunmayı içermekle birlikte, müşterinin satın alma sonrasında talep ettiği bir istek veya şikâyeti, yine değer merkezli bir yaklaşımla geri dönüş sağlanmasını ve tüketicinin/müşterinin sahip olduğu ürünü tavsiye edebilecek seviyede memnun olabilmesini de sağlamayı kapsamaktadır.

Çalışmamızda, müşteri deneyimini sürdürülebilir ve yüksek seviyede tutmayı amaçlayan çevik dönüşüm süreci modeli, temelde 7 farklı ana unsurdan oluşmaktadır. Bu unsurlar; Organizasyon, Çevik Altyapı, Örgütsel Kültür, Değişim Yönetimi, Ürün Yönetimi, İş Değeri, Sürdürülebilirlik. Bu unsurlar da aşağidaki tabloda (Tablo.6) görüldüğü üzere kendi içerisinde alt faktörlere sahiptir.

Organizasyon; çevik yönetim sürecinde ana unsurlardan birisi, "Organizasyon" olarak belirlenmiştir. Organizasyon, kendi içerisinde Birey, Takım, Çevik Lider başlıklarından oluşmaktadır. Çevik dönüşüm sürecinde, müşteri odaklı bir perspektifle şirketin mevcut organizasyon şeması, görev tanımları ve birimler arası ilişkilerin birey, takım, lider özelinde yeniden tanımlanmalıdır. Çevik süreç dinamiği gereği, hızlı karar almayı hedefleyen, bürokrasinin azaldığı daha yatay hiyerarşik yapılar ile organizasyon şemaları oluşturulmalıdır. Organizasyonel dönüşüm ile yeni görev ve sorumluluklar ortaya çıkması ile bireylerin yeni bir öğrenme, uygulama sürecine girmesi söz konusu olacaktır. Bu dönüşümün birey özelinde oluşabilecek tüm sorulara anlamlı ve yeterli yanıtlar verebilmesi bireyin motivasyon, iş tatmini ve duygusal bağlılığını etkileyerek bireyin adaptasyon, performans ve üretkenliğini etkilenebilecektir. Özellikle, çalışanın mevcut yapıda bildiği ve konfor alanında olduğu görev tanımının farklılaşması, birey üzerinde korku, yetersizlik ve gelecek belirsizliğine sebep olabilecek ve bireyin öznel iyi oluşunu etkileyebilecektir. Dönüşümün amacına uygun tesis edilmesi için sürecin boyutlarının birey tarafından benimsenmesi ve desteklenmesi için fiziksel ve psikolojik olarak bireyler hazır hale getirilmelidir. 
Tablo 6. Çevik Dönüşüm Süreci Modeli

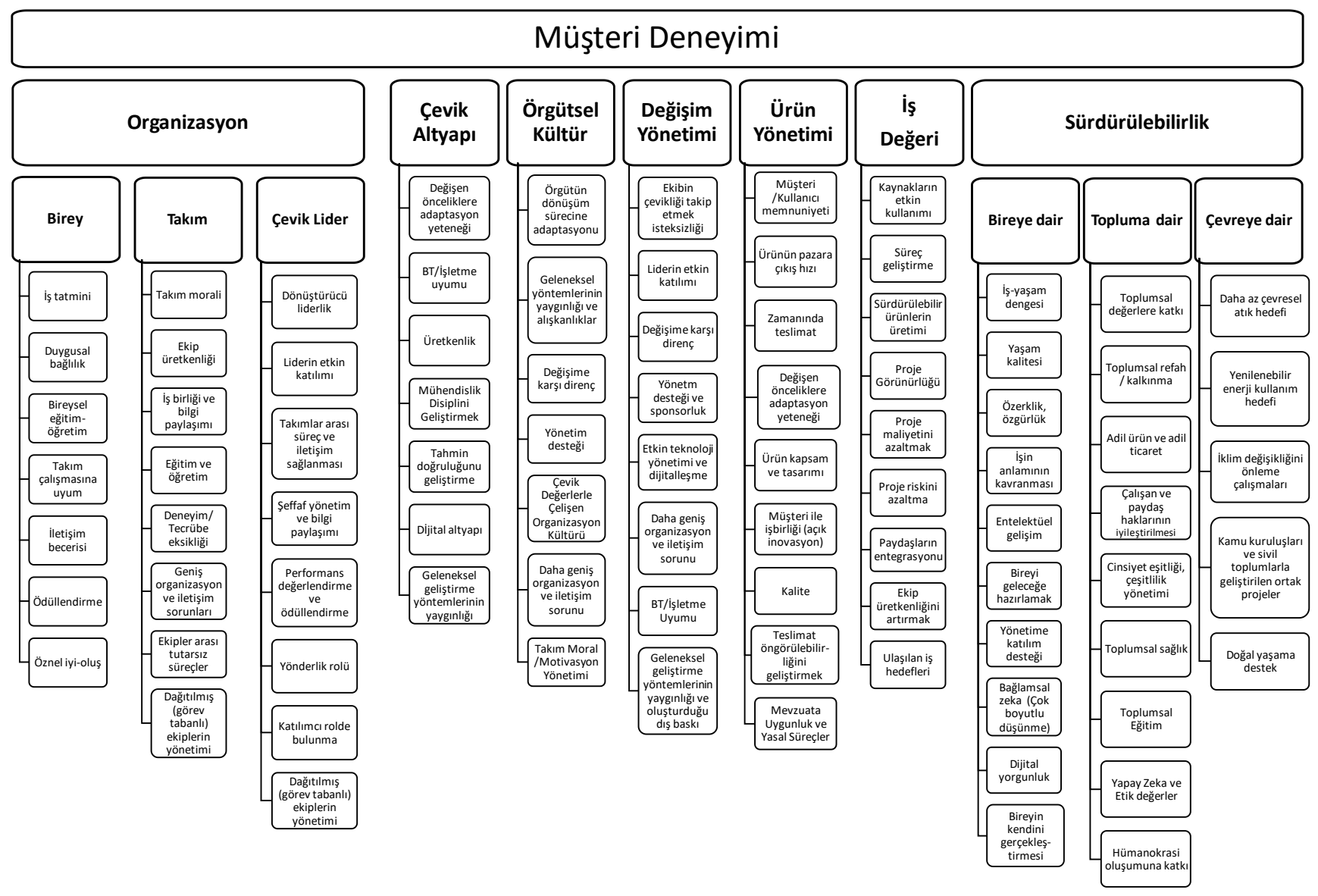

Organizasyonun dönüşüm içerisinde yeni görev tanımlarının, rollerin belirlenmesi ve iletişimde olan birimlerle olan iş akışlarının, performans kriterlerinin ve ödüllendirmenin süreç başında kurgulanması sağlıklı bir başlangıç için önem arz etmektedir. Dönüşüm sürecinde, görev masalarına uygun olarak yetkinlik, beceri ve heves yönünden doğru profildeki adayların belirlenmesi dönüşüm sürecinin kilit noktalarından birisidir. Uygun adaylara gerekli eğitim ve bilgiler verilerek bu süreçle elde edeceği kazanım ve tecrübeler paylaşılması, bireyin öznel iyi oluşunu sağlayacak yönetsel destek verilmesi çalışanın devamlılı̆̆ı, uyumluluğu ve iş tutumlarını olumlu etkileyebileceği düşünülmektedir. Ayrıca, çevik yaklaşım felsefesi gereği müşteri memnuniyetini sürekli kılmak için organizasyonun yeniden yapılandırma sürecinde bilginin kimsenin tekelinde olmadığı, birbirini yedekleyebilen görev masalarının oluşturulması sağlıklı bir dönüşüm sürecinin önemli gerekliliklerindendir.

Organizasyon içerisindeki takımların rolleri önemli bir diğer etken faktör olarak ele alınması gerektiği düşünülmüştür. Çevik dönüşüm sürecindeki takım anlayışı kültürünün çekirdeğini müşteri deneyimi oluşturmaktadır. VUCA ortamı içerisinde dış faktörlerden kaynaklı değişim zorunluluğu, çalışma takımlarını dinamik bir yapı içerisinde olmaya zorlamaktır. Takımlar ve takım içerisindeki bireyler arasındaki iş süreçlerinin şeffaf, paylaşımc1, katılımc1, sinerji kültürü ile kurgulanması katma değerli sonuçlar üretmenin temeli oluşturduğu düşünülmektedir. Çevik dönüşüm sürecinde, iş yapma modellerindeki değişim sonucu yeni görev, takım ve çalışan ihtiyacı organizasyona yeni bireylerin katılması ve genişleyen organizasyon ile oluşabilecek eğitim/deneyim eksikliği, iletişim sorunları ekip üretkenliğini olumsuz etkiyecek olup yüksek hassasiyet gösterilmesi gerekmektedir.

VUCA ortamının baskısında şirketler, organizasyonun sürekli değişen öncelikleri doğru okuyabilme, doğru anlamlandırabilme ve takımların etkin yönetimi ile doğru aksiyon planlarının alınmasını sağlayabilecek dönüştürücü liderlik özelliklerinde çevik liderlere ihtiyaç duyarlar. Çevik yaklaşım gereği olarak, pazara hızlı yanıt verebilme özelliğini sağlayabilmek için takım ve bireyler arasındaki bilgi alışverişinin ve iş akışının kesintisiz ilerleyebilmesi gerekmektedir.

Çevik lider, dönüşümün sorunsuz yürütülebilmesi için takım ve bireylerin süreçle alakalı olası soru, şüphe ve kaygıyı ortadan kaldıracak netlikte yanıtlar sunarak, ekibin çevik süreci içselleştirmesini sağlamalıdır. 
Motivasyon ve ödüllendirme araçlarının etkin yönetimi ile ekibi canlı, hevesli ve üretken olmasını sağlayacak doğru soru ve yönlendirmeler yapmalıdır. Ayrıca, çevik lider tersine mentorluk yaparak üst yönetimin desteğini dönüşüm sürecine odaklandırmalı ve katkı yapmalarını sağlayarak süreci sahiplendirmeye çalışmalıdır.

Dönüşüm sürecinin ilk dönemlerinde, çalışanlara yeni rollerin üstlendirilmesi ve organizasyona olası katılacak yeni bireylerin adaptasyonu ve iletişim konuları çevik liderlerin etki alanına giren majör konulardandır. Çevik liderler, dış dünya ile etkileşim halinde bulunarak pazar ve müşteri taleplerini doğru okuma sürecinin içerisinde bulunmalı, aynı zamanda organizasyon içerisinde pozitif yönetim yaklaşımı sergileyerek katma değerli süreçlerin ortaya çıkarılması ve sorunlara yönelik potansiyel tüm çözüm alternatiflerin değerlendirilebilmesi için cesaret verici, şeffaf, katılımcı, ifade özgürlügünü temin eden ve bireylere hata yapma firsatı sunan bir yönetim yaklaşımı benimsemelidir.

Çevik Altyapı; çevik dönüşüm sürecinin ikinci ana unsuru olarak "Çevik Altyapı" belirlenmiştir. Çevik yönetim yaklaşımın, üst yönetim kademesinde düşünsel olarak benimsenmesi uygulamada başarılı olacağı anlamı taşımamaktadır. Bu sebeple etkin bir dönüşüm için çevik yaklaşımın gerekliliklerine uygun olarak gerekli alt yapı ve iş yapma modellerinin yeniden gözden geçirilmesi gerekebilecektir. Üretim altyapısı değişen önceliklere hızlı uyum gösterebilecek esnekliğe sahip olabilmeli, birincil kaynaklardan bilgiye ulaşım hızını artırabilecek dijital dönüşüm ile işletme süreçleri daha şeffaf hale getirilmesi sağlanmalıdır.

Pazarın değişen önceliklerine adapte olabilmek, işletmeleri standart ve rutin üretim süreçlerinin dışında yeni iş modelleri ve esnek üretim altyapısı geliştirmeye zorlayacaktır. Bu durumun yan etkisi olarak, kalite, zaman ve fire kayıpları ile başa çıkabilmek için tahmin doğruluğunu geliştirecek metotların belirlenmesi ve yalın üretim, sürekli iyileştirme çalışmaları ile değer yaratmayan süreçlerin ortadan kaldırılmasını hedefleyen içe dönük çalışmalar gerekebilecektir.

Çevik altyapı süreçlerinde değerlendirebileceğimiz bir diğer süreç de, tedarik zinciridir. Bir ürünü meydana getiren bileşenleri ve bileşenleri meydana getiren hammadde ve malzemelerin doğru kalitede ve doğru zamanda temin edilmesine bağlı olarak ürünün pazara çıkış hızı, müşteri servis seviyesi, üretkenlik ve verimlilik doğrudan etkilenebilecektir. Özellikle dönüşüm sürecinde, güvenilir ve sürdürülebilir tedarikçilerin oluşturulması müşteri deneyimini artırmada kritik role sahip olacaktır.

Örgütsel Kültü̈r; çevik dönüşüm sürecinde "Örgütsel Kültür” ana unsurlardan birisi olarak kabul edilmiştir. Müşteri memnuniyetini sürekli sağlayabilecek bir dönüşüm anlayışı şirketin iş yapma kültüründe ve yaklaşımlarında bazı değişiklikleri de beraberinde getirecektir. Çevik dönüşüm ile yeni süreçlerin ortaya çıkması şirket içerisindeki bazı güç dengelerinin değişmesini, bazı yöneticilerin sahip oluğu etki alanını kaybetmemek adına direnç gösterebilmesi ve üst yönetim desteğinin yetersiz seviyede kalması dönüşüm sürecini zorlaştıracak bazı faktörler olarak düşünülebilir. Ayrıca çevik yaklaşımda müşterinin ürün ile ilgili daha fazla söz sahibi olması sebebiyle iş süreçlerine daha fazla entegrasyonu sonucu bazı kültür ve değerlerin yeniden yorumlanabilmesine neden olabilecektir.

Dönüşüm sürecinin, yapılanma sürecinde geleneksel metotların yaygın kullanımında ısrar edilmesi ve yeni çalışanların organizasyona katılması ile oluşabilecek iletişim sorunları ve doku uyuşması hem mevcut yapıdaki çalışanların hem de yeni katılan bireylerin organizasyona olan bağlılığını, uyumunu ve motivasyonunu etkileyebilecektir. Bu sebeple, dönüşüm sürecinin kavramsal tasarım sürecinde örgütsel kültür öğelerine özel önem verilmesi ortak değerler etrafında birleşme ve sinerji ruhunun oluşturulmasında büyük önem taşımaktadır.

Değişim Yönetimi; çevik yönetim sürecinde dönüşüm sürecini zorlayabilecek en güçlü unsurlardan birisi olarak değerlendirilebilir. Dönüşüm sürecinde çalışanların iş yapma alışkanlıklarını devam ettirme isteği, konfor alanlarını terk etmeme tutumu, bilinmeze karşı korku ve gelecek kaygısı bireylerin çevik dönüşüm sürecine direnç göstermesi ile sonuçlanabilir. Nitekim önceki bölümlerde ele alınan çevik yönetimi benimsemede yaşanan zorluklar arasında katılımcılar tarafından her yıl en yüksek oranı alan "Değişime karşı genel organizasyon direnci" yanıtı olmuştur. Ekibin çevik dönüşümü takip etme isteksizliğini ve değişime olan direnci minimum etki seviyesine indirebilmek için birey ve takımlarca dönüşüm sürecinin tüm boyutları ile kavranması sağlanmalı, işgörenlerce sürecin içselleştirilmesi için destek algısı hissedilmeli, güncel sorumluluklarına uygun olarak eğitimler verilerek bireyin özgüveni tesis edilmeli, hata yapma özgürlüğü tanınmalı ve geleceğe hazırlanmalıdır. Aksi durumda, işgörenlerde moral/motivasyon kaybı yaşanacağı, performanslarında düşme meydana geleceği, iş tatmin seviyesinin azalacağı, örgütsel bağlılıkları zayıflayacağı ve bireyi, organizasyondan ayrılma kararı almaya kadar götürebilecektir.

Dönüşüm sürecinde organizasyon içerisinde mevcut rol, yetki, sorumluluk ve güç dengelerinin yeniden tasarlanması gerekebilecektir. Bazı kıdemli ve organizasyon içerisindeki güçlü yöneticilerin etki alanlarını 
yitirebilme kaygısı ile engelleyici söylem ve eylemlerde bulunması ve diğer çalışanlar üzerinde bir direniş oluşturması bu süreçte beklenebilecektir. Bu türden sorunların üst yönetim desteği ve yüksek derecede yetkilendirilmiş dönüştürücü lider özellikli yöneticiler ile aşılabileceği düşünülmektedir.

Şirketin kendisini geleceğe taşıma ve rekabet avantajı elde etme hedefi ile çevik dönüşümü benimsemesi için başlanılan yönetsel niyet ve tutum süresince, aynı sektör içerisindeki rakiplerden benzer bir aksiyon alınmaması ve rakiplerin mevcut iş modellerini devam ettirmesi dönüşen organizasyon içerisinde bir diş baskı oluşturabilecektir. Özellikle dönüşümü yürüten sorumlu proje ekibinin ve üst yönetimin işgörenlere süreci sahiplendirecek yönlendirmeler yapması gerekmektedir. Sürecin doğru yürütülememesine ek olarak dış baskının içeride oluşturduğu etki ve içerdeki değişim direnişinin birleşmesi ile örgütten kopmalar meydana gelebilecek ve artan sayıdaki her ayrılık örgütsel güvenin sarsılmasına ve dönüşüm projesinin başarısızlıkla sonuçlanmasına sebep olabilecektir.

Çevik dönüşümün alt boyutlarından olan dijital dönüşüm ile veri ve bilgi akışının da dijital ortamlara taşınarak yönetsel karar alma süreçlerinin kolaylaşması ve hızlı olmasını sağlamak mümkün olabilmektedir. İşletme ve iş süreçlerinin, bilgi teknolojilerine entegrasyonu sayesinde, organizasyonlar daha sağlıklı büyük veri yönetimleri ile çalışma imkânı bulunabilecek ve tüketici, müşteri, ürün, tedarik süreçleri ile ilgili anlamlı analiz ve değerlendirmeler yapılarak fayda sağlanabilecektir. Ek olarak, mevcut iş uygulamalarında ve idari süreçlerde kullanılan yazılı belge, prosedür, talimat ve formların dijital ortamlar üzerinden hareket etmesi, hızlı karar alınmasını sağlayacak altyapının oluşmasına ve çevik yaklaşım dinamiğine uygun bir dönüşüm olacaktır.

Ürün Yönetimi; çevik yönetim sürecinde "Ürün Yönetimi” işletmeleri zorlayacak bir diğer ana unsurdur. Günümüz dünyasında, tüketim alışkanlıkları değişmiş, ürün yaşam döngüleri kısalmış (veya akıllı eskitme ile kısaltılmış), değişim hızına ek olarak, popüler kültürün de etkisi ile bir ürün dakikalar içerisinde dünyanın öteki ucundaki kimselere ulaşıp rağbet görmesini sağlayan güçlü sosyal medya paylaşımları, şirketleri sürdürülebilir müşteri memnuniyeti sağlayacak ürün yönetimi konusunda çevik yaklaşımları benimsemeye zorlamaktadır.

VUCA ortamında ürün yönetimi sürecinde, ürün yaşam süresinin kısalması ile müşterinin talep ettiği ürünü belirlemek, ürünün ilk pazara çıkış performansı ve tüketiciye ulaştıran teslimat hızı konuları kritik önem derecesine gelmiştir. Üretebilme yeteneği, gerekli altyapı ve teknolojinin genel olarak ucuzlaması ile ulaşılabilir olmuş, bu durumun oluşturduğu maliyet ve rekabet baskısı, ürününün kapsamı ve özellikleri konusunu daha farklı bir boyuta taşımıştır. Ürün kapsamı, tasarlanma ve pazarlanma sürecinde, ilişkisel pazarlama yöntemlerinin tercih edilmesi, açık inovasyon adımları ve müşteri işbirliğinin sağlanması ile doğru kalite, fiyat ve özelliklerin belirlenmesi, yine aynı süreçle müşteride katma değer yaratmayan işlemlerin ortadan kaldırılması için değer zinciri analizleri yapılması VUCA ortamının olumsuz etkilerini azaltabilecek yönde olan gelişmeler olacaktır.

Müşterinin satın almak istediği ürünün ve markanın toplumsal değerlerle çatışmaması, yasal kural ve mevzuatlara uygun olması, tercih edilme yönünden daha geniş kitlelere ulaşabilmeye imkân tanıyacaktır. Diğer yönden, sosyal medya araçlarında, gerek devlet/bakanlık düzeyinde gerekse nihai tüketicilerin ürünlerde tağşiş, tüketiciyi aldatmaya yönelik içerik konusunda yapılan usulsüzlüklerin tespit esilmesi ile internet dünyasında hızla çevrimiçine girebiliyor, yüksek tepki ve paylaşımlarla markanın ve ürünün itibarına zarar gelebilecek durumlar ile karşılaşllabilmektedir. Uçtan uca tedarik zinciri ve üretim faaliyetlerinde izlenebilirlik süreçleri ile yapılacak kontrol ve denetim sağlayabilmek müşteri deneyimini etkileyebilecek temel faktörlerdendir.

İş Değeri; çevik dönüşüm sürecinde ana unsurlardan birisi de "İş Değeri” olarak belirlenmiştir. İş değeri başlığında, şirketin sürdürülebilir şekilde varlığını devam ettirebilmesi sahip olduğu tüm kaynaklarının etkin ve verimli kullanılmasına dayanmaktadır. Daha geniş manada iş değeri, şirketin sahip olduğu entelektüel sermayesi, iş modeli, müşteri, tedarikçi, çalışan, marka gücü, topluma sunduğu değerlerin tamamını kapsar niteliktedir.

Çevik yaklaşımın benimsenmesi değişen önceliklere uyum becerisi şirketin iç süreçlerinde yönetsel bazda bazı güçlükleri beraberinde getirecektir. Bu durumda, finansal ve mali kaynakların, insan kaynaklarının, üretim kaynaklarının ve maddi olmayan kaynakların, müşteri beklentileri ve işletmelerin sürdürülebilir kârlılık \& büyüme ilişkisinde hassas dengede yönetilmelidir. Her bir proje ve çalışmanın tedarik, üretim, maliyet, fiyat ve sürdürülebilirlik analizleri ve detaylı risk faktörlerinin belirlenmesi, müşteri yönünde katma değer yaratan süreçlerin kurumsal faydasının belirlenmesi aşamasında büyük öneme sahiptir. Ayrıca, VUCA ortamının ve pandemi süreci ile olumsuz etkilenen tedarik zinciri süreçlerinin üzerine, küresel düzeyde ekonomik, sağlık, politik ve ticari hayattaki belirsizlikler ve karmaşıklıklar; yatırımdan en küçük pazarlama harcamasına kadar karar alma süreçlerini güçleştirmektedir. Bu gerekçelerle, şirketlerin değişen öncelikleri yönetebilmek ve 
fırsatları karşılayabilecek dijital, yalın, esnek, üretken ve izlenebilir altyapı ile sürdürülebilir müşteri deneyimi temin edecek çevik organizasyon ve yönetsel yaklaşımlar benimsenmesi gerektiği düşünülmektedir.

Sürdürülebilirlik; çevik yönetim sürecinde "Sürdürülebilirlik" başlığı şirket geleceğinin teminatı olarak değerlendirilmekte olup ana unsurlardan birisi olarak belirlenmiştir. "Yıllık Çevik Durum Raporları" incelendiğinde, sürdürülebilir yaklaşıma bağlı olarak hedeflerin eksikliği tespit edilmiş ve geliştirilen model önerisinde sürdürülebilirliğin ana başlık olarak belirlenmesi gerektiği düşünülmüştür. Çevik yönetim sürecinde "Sürdürülebilirlik" ana başlığımız, "Bireye dair", "Topluma dair", "Çevreye dair" olarak üç alt başlıkta incelenmiştir.

Kâr amacı güden işletmelerin majör hedeflerinden birisi sürdürülebilir, büyüme ve kar elde etmektir. Bu amaçla bulunduğu sektördeki tüm paydaşlarla sürdürülebilir bir ilişki kurması ve müşteri deneyimini artıracak ürün/hizmet sunumu sağlayarak sadık müşteriler oluşturmak ve geleceğini teminat altına alma hedefinde bulunmalıdır. Sürdürülebilirlik anlayışı son yıllarda artan bir eğilimle, gerek toplumsal sosyal sorumluluk, gerekse sektör öncülerini takip etmek bazen de pazarlama faaliyeti olarak değerlendirilerek yönetim hedefleri arasına giren kavramlardandır.

Sürdürülebilirlik ana unsurunun "Bireye dair" alt başlığında, çevik dönüşüm sürecinde işletmelerin müşteri deneyimini sürekli kılacak insan kaynağının bugünün ve yarının ihtiyaçlarını karşılayabilecek şekilde donatılması gerekmektedir. Bireyin teknolojik değişime ayak uydurması yeni beceri kazanması ve sahip olduğu becerileri geliştirmesine kurumsal olarak destek olunması örgütsel gelişim noktasında önemli dönüm noktalarındandır. Aksi takdirde gelişen teknoloji ve otomasyon, makine öğrenimi ve yapay zekâ uygulamaları insanların işlerini kolaylaştırırken bireyler üzerinde gelecekte kaygısı oluşturabilecektir. Bu noktadan hareketle, birey merkezli gelişim yol haritaları çıkarılarak örgüt içerisindeki yetenek ve potansiyellerin belirlenip entelektüel gelişimine katkı sunacak eğitim programları ile kişisel ve kurumsal kazanımlar gözetilmelidir.

Geleneksel olarak kurumsal yönetim anlayışında, psikolojik faktörlere ilişkin incelemelerin örgütsel düzeyde kaldığı ifade edilebilir. Diğer bir ifade, birey takımın bir parçası ve takım genel olarak memnun, örgütsel bağlılığı yüksek, motivasyon düzeyi iyi ise birey özelindeki incelemeler göz ardı edilir. Özellikle son yıllarda, eğitim-öğrenim seviyesinin yükselmesi ile çalıştığı kurumdan ne istediğini bilen bireylerin sayısının artması, emeklilik yaşlarının uzaması ile ömür boyu çalışma kültürü içerisinde olacak bireylerin iş-yaşam dengesi konusundaki hassasiyetlerinin artmasını doğurabilecektir. Y kuşağının özgür, esnek ve bağımsız çalışma talebi (Düzgün, 2020:223), dünya vatandaşı olan Z kuşağı bireylerin (Sladek ve Grabinger, 2013:4) yer değiştirme tabusunun olmayacağı beklentisi, örgütsel vatandaşlık, örgütsel bağlllık, örgütsel motivasyon, iş tatmini konularının bireye özgü bir bakış açısı ile yeniden yorumlanması ve kurgulanması gerektiği düşünülmektedir.

Uzaktan çalışmanın benimsenmesi, bilgi işçileri üzerinde dijital yorgunluğa maruz bırakabilecek ve yeni tip rahatsızların oluşmasına sebep olabilecektir. Diğer taraftan, dijitalleşmenin de etkisi ile uzaktan çalışma kültürü içerisinde, bireyin izole olma durumundan kaynaklı kendi psikolojik sermayesini kuvvetlendirecek, öz yeterliliği sağlayacak iç güdüleme sürecini ve telkinleri doğru yönetmeyi öğrenmesi gerekmektedir. Örgüt olarak, insan kaynakları yönetimine bağlı olarak gerek psikolojik destek departmanlarının kurulması ve/veya çevik liderler tarafından, çalışanların şirket hedeflerinden ve amaçlarından kopmaması için gerekli motivasyon, teşvik ve desteklerin verilmesi örgütsel çıkarlar ve toplumsal fayda için daha da önem arz edeceği düşünülmektedir (Koç vd., 2020:137).

İş ve ticari hayatın gerekliliklerini yerine getirmek için organizasyonların ve gerekli altyapılar, mekanik yapılara dönüşmemelidir. Daha geniş manada, işgörenler uyanık olduğu vakitlerin çoğunu bulunduğu iş zamanı içerisinde geçmektedir ve bu durum, bireyde psikolojik yorgunluk ve duygusal tükenmişliğe sebep olabilecek ve iş performansını doğrudan etkileyebilecek boyutlara dönüşebilecektir. Çevik yaklaşımın temelinde var olan yüksek sinerji ve iletişimi tesis edebilmek için bireyin hayattan beklentilerinin bilinmesi ve kendini gerçekleştirmek için moral/motivasyon, destek sağlanması ve kurumun insana saygı duyan yaklaşımlar benimsemesi sosyal bir sorumluluk olup ticari geri dönüşlerinin de olacağ değerli süreçler ile yüksek potansiyele sahip, yetenekli ve yetkin adayların çevik organizasyonlara dahil olma hevesi oluşturabilecek ve daha çok seçenek arasından uygun profildeki kişilerin istihdam edilmesi kolaylaşabilecektir.

Pandemi dönemi ile birlikte sağlık ve salgın konusu birey özelinde önemli argüman olarak belirmiştir. Artık bireylerin yeme, içme alışkanlıklarında bireysel sağlıklarına önem vermesi, bazı lüks harcamalarını azaltması ve işini kaybetmesi veya kısıtlı çalışması ile oluşan gelir kayıplarını telafi edebilmek için tasarruf yapma konularında bazı tutum değişikliklerine gidebileceği düşünülmektedir. $\mathrm{Bu}$ durum bireyin harcamalarını ve birikim kararını doğrudan etkileyebilecek olup, işgöreninin yegâne gelir kaynağı olan ücreti daha yüksek 
seviyede talep edebileceği ve yakın gelecekte ücretin iş tatmininin ve örgütsel bağl1lık içerisindeki rolünün değişebileceği tahmin edilmektedir.

"Sürdürülebilirlik" ana unsurunun altındaki ikinci alt başlık "Topluma dair" katma değerli süreçlerin birer hedef halinde yönetilmesi öngörülmüştür. Gerek tüketicilerin satınalma davranış1 (Külter, 2015:68) gerekse çalışanların (Demir ve Türkmen, 2014:54) örgütsel bağl1lıkları kurumların sosyal/toplumsal sorumlulukları ile pozitif bir ilişkide olduğu ampirik çalışmalarla ortaya konmuştur. Bazı şirketler, maddi kazanım elde ettikleri gelirlerin bir bölümünü içinde bulunduğu toplumla paylaşarak, paydaş kültürünü genişleten bir anlayışa sahiptir. Genel olarak şirketlerin bu özellikleri, bir tür pazarlama faaliyeti değerlendirileceği gibi şirketleri için uzun vadede karlılık üzerine pozitif katkı sunduğu yapılan çalışmalarla ortaya konmuştur (Yusuf ve Tekin, 2018:28; Wang vd., 2016:19; Arsoy vd., 2012:172).

Son yıllarda teknoloji ve bilgiye ulaşım araçlarının artması ile birlikte tüketim alışkanlıklarının değişmesine sebebiyet veren, insanların kendi özünü ve benliğini daha fazla tanımasına, sınamasına, topluma ve doğaya karşı sorumluluklarını düşünen, etik ve adil ticareti destekleten tüketici profilinde artış meydana gelmiştir (Koç vd., 2020:136; Erol, 2017:143). Müşteri deneyimini artırma hedefindeki şirketler, topluma sundukları değer üreten, yenilikçi ve örnek uygulamalar ile rekabet avantajı elde edebilirler. Sivil toplum ve kamu kuruluşları ile birlikte, toplumsal adalet, cinsiyet eşitliği, toplumsal refahı ve sağlığı gözeten ortak projeler, müşteri tatminine katk1 sunarak yeniden satın alma tutumu içerisine girmesine hizmet edebilecektir.

"Sürdürülebilirlik" ana unsurunun altındaki son alt başlık "Çevreye dair" hedefler olup çevik dönüşüm sürecinde önemle üzerinde durulması gerektiği düşünülmektedir. İklim değişiklikleri, üretim sırasındaki karbon salınımdaki artışla hava, toprak ve su kirliliğine sebep olması ve verimlilik kayıpları, artan nüfus ve kaynakların kısıtlı olması durumları bir araya getirildiğinde, atık üreten işletmelerin çevreye dair etkisini azaltacak hedef eklemeleri çevresel ve toplumsal sorumluluklarından olduğu düşünülmektedir.

Çevik dönüşüm sürecindeki işletmeler, hammaddenin üretilmesinden, nihai müşteriye sunulması ve kullanıldıktan sonra geri dönüşüm sürecini de dâhil eden bir yaklaşımla işletmelerin tüm tedarik zinciri süreçleri analiz edilmeli ve iş ortaklarına daha az atık oluşturacak ortak projeler ve yenilenebilir enerji kaynakları kullanmak için gerekli teknoloji yatırımları yapması yönünde çalışmalar yürütmelidir. Çevreye duyarlı proje geliştiren şirketlerin müşteriler tarafından satınalma davranışlarını olumlu yönde etkilemesi ve müşteri memnuniyet seviyesini artırması deneysel çalışmalarla da ortaya konulmuştur (Erbaşlar, 2012:101; Kardeş, 2011:175; Ay ve Ecevit, 2005:260).

Çevik dönüşüm süreçlerinde, dijital dönüşüm ile kâğıt belge kullanımını azaltacak altyapı kurulması, takım ve birey bazında karbon ayak izini azaltacak hedefler tanımlanması ve yenilenebilir enerji kaynakları ile enerji ihtiyacının maksimum seviyede karşılanması için geliştirilen çalışmalar tüm paydaşlar ve müşteri özelinde anlam ifade edebilecek ve şirketin sürdürülebilir hedeflerine katkı sağlayacaktır.

Dış dünyadaki hızlı değişim rüzgârına adapte olabilmek için yönetim alanında güncel arayışlar yoğun bir şekilde devam etmektedir. Çevik yaklaşım vizyonu, çevresel her türden etmeni dikkate alması, otonom, özerk ve katılımcı demokrasi yolu ile sorumlulukları takım seviyesine indirgemektedir. Rapor incelemelerinde, uygulama sürecinin içselleştirilmesinin ardından çözüm üretici yapısı ile işgörenlerin organizasyona sağlamış olduğu yüksek katkılar katılımcıların görüşleriyle vurgulanmıştır.

Dönüşüm sürecinde, dönüşüm niyetinin ve iradesinin ortaya koyulması ve sürecin dönüşüm liderleri tarafindan hassas bir şekilde takip edilmesi sağlıklı ilerlemenin ahatarıdır. $\mathrm{Bu}$ sürecinin uygulama aşamasında organizasyon içerisinde gönülülük esasına göre pilot takımlar ve uygulama alanları belirleyerek örgüt tarafindan içselleştirilmesi sağlanmalıdır.

Organizasyonların büyük ve geniş yapıda olması bu türden büyük bir dönüşümün nasıl olacağına dair soru ve kaygılar oluşturabilmektedir. Çevik yönetim, yüzünü dış dünyaya çevirmiş bir yaklaşımı ve kendi içerisinde çok iyi organize olmuş takım oyuncuları ile sürekli gelişim rotası ile geleceğe adım atar. Bu süreçte, çevik dönüşüm sürecini bir maraton koşusu şeklinde tanımlayarak, kültür ve vizyon değişiminin tüm organizasyon tarafından sahiplenilmesi sağlanıncaya dek devam etmelidir. Büyüme ve gelişim odaklı proje usulü iş yapan, nispeten daha az çalışan sayısına sahip işletmelerde ise topyekün bir dönüşüm anlayışı benimsenerek çevik yönetim vizyon ve yöntemleri ile müşteri deneyimi, çalışan memnuniyeti, iş değeri, üretkenlik ve teslimat performans1 gibi birçok kritik performans göstergesinde başarı elde edebilir.

Çevik yönetim uygulamasının Türkiye'de benimsenmesinin artması ile bu çalışma kapsamında analiz edilen “Yıllık Çevik Durum Anketi”nin benzeri çalışmaların gerçekleştirilmesi ile ülkemiz özelinde var olan dönüşüm 
dinamikleri ve iş kültürünü incelemek üzere daha derinden incelemeler yapmak mümkün olabilecektir. Çevik yönetim uygulamalarının sektör ve iş kollarına özgü alanlarda nasıl farklılaştığı, derinleştiği ve hangi alternatif yöntemlerin geliştirilmesi gerekliliği yeni çalışmalarla ortaya konularak literatür zenginleştirilebilir.

\section{KAYNAKÇA}

AGHINA, Wouter, SMET, Aaron De ve WEERDA, Kirsten (2015), "Agility: It Rhymes with Stability" McKinsey Quarterly, S.2015(December), ss.1-12, https://www.mckinsey.com/businessfunctions/organization/our-insights/agility-it-rhymes-with-stability (Erişim Tarihi: 01.05.2021).

AGILEALliANCE (2021), "The Agile Manifesto", Agile Alliance (E-Article), https://www.agilealliance.org/agile101/the-agile-manifesto/ (Erişim Tarihi: 01.12.2020).

AKÇAY, Abdülkadir (2019), "İ̧ Motivasyon Araçlarının ve Eğitim-Geliştirme Faaliyetlerinin Çalışanların İş Üretkenliğine Etkisi”, Doktora Tezi, Süleyman Demirel Üniversitesi Sosyal Bilimler Enstitüsü, Isparta.

ARSOY, Aylin Poroy, ARABACI, Özer ve ÇífTÇíOĞLU, Aydem (2012), "Corporate Social Responsibility And Financial Performance Relationship: The Case of Turkey", Muhasebe ve Finansman Dergisi, S.14, ss.159-176.

AY, Canan ve ECEVİT, Zümrüt (2005), "Çevre Bilinçli Tüketiciler”, Akdeniz Üniversitesi İïBF Dergisi, S.10, ss.238-263.

BAL, Barış (2020), “ACM Agile’’n Yönetici Ortă̆ı İle İş Dünyasını Çevik Dönüşüm Uygulamalarıyla Geleceğe Hazırlamak Üzerine”, Harvard Business Review Türkiye, https://hbrturkiye.com/dergi/acm-agile-inyonetici-ortagi-ile-is-dunyasini-cevik-donusum-uygulamalariyla-gelecege-hazirlamak-uzerine (Erişim Tarihi: 02.11.2020).

BARBER, Herbert F. (1992), "Developing Strategic Leadership: The US Army War College Experience", Journal of Management Development, S.11(6), ss.4-12.

ÇIÇEKLİOĞLU, Hüseyin (2020), “Örgütsel Değişsim ve Değişim Yönetimi”, Örgütsel Davranış (Ed. İsmail Bakan), Beta Yayınları, İstanbul, https://www.academia.edu/44592337/B\%C3\%96L\%C3\%9CM_22_\%C3\%96RG\%C3\%9CTSEL_DE\%C 4\%9E\%C4\%B0\%C5\%9E\%C4\%B0M_VE_DE\%C4\%9E\%C4\%B0\%C5\%9E\%C4\%B0M_Y\%C3\%96NE T\%C4\%B0M\%C4\%B0 (Erişim Tarihi: 02.11.2020).

DEMIR, Rıza ve TÜRKMEN, Erman (2014), “Çalışanların Kurumsal Sosyal Sorumluluk Algllarının Örgüte Bağlllıkları Üzerindeki Etkisinin İncelenmesine Yönelik Bir Araştırma”, Aksaray Üniversitesi İktisadi ve İdari Bilimler Fakültesi Dergisi, S.6(2), ss.47-59.

DEVOR, Richard, GRAVES, Robert ve MILLS, John J. (1997), "Agile Manufacturing Research: Accomplishments and Opportunities", IIE Transaction, S.29, ss.813-823.

DÜZGÜN, Ayşegül (2020), " $Y$ ve Z Kuşaklarının Işş Hayatından Beklentilerinin Karşılaştırılması", Hitit Üniversitesi Sosyal Bilimler Enstitüsü Dergisi, S.13(1), ss.218-241.

ERBAŞLAR, Gazanfer (2012), “Yeşil Pazarlama”, Mesleki Bilimler Dergisi, S.1(2), ss.94-101.

EROL, Fuat (2017), "Bir Etik Tüketim Aracı Olarak Adil Ticaret”, Afyon Kocatepe Üniversitesi İktisadi ve İdari Bilimler Fakültesi Dergisi, S.19(2), ss.143-154.

FINDSRUD, Rolf (2020), “An Agile Approach to Service Innovation: Creating Valuable Service Innovation with Agile Resource Integration", Journal of Creating Value, S.6(2), ss.190-207.

FLORA, Harleen K., CHANDE, Swati V. ve WANG, Xiaofeng (2014), "Adopting an Agile Approach for the Development of Mobile Applications", International Journal of Computer Applications, S.94(17) ss.43-50.

GABLAS, Branislav, RUZICKY, Eugen ve ONDROUCHOVA, Martina (2018), "The Change in Management Style during then Course of a Project from the Classical to the Agile Approach", Journal of Competitiveness, S.10(4), ss.38-53. 
JAVANMARD, Mahdi ve ALIAN, Maryam (2015), "Comparison Between Agile And Traditional Software Development Methodologies", Cumhuriyet Üniversitesi Fen Fakültesi Fen Bilimleri Dergisi (CFD), S.36(3. Özel Say1), ss.1300-1949.

KARDEŞ, İlke (2011), "Markaların Çevre Dostu Uygulamalarının Tüketicinin Marka Tercihi Üzerindeki Etkisi”, Ege Akademik Bakış Dergisi, S.11(1), ss.165-177.

KOÇ, Murat, ÖZBAY, Meltem, KOÇAK, Gizem ve ÖZEN, Muhammet Tuğrul (2020), Yönetim Perspektifinden Pandemi Dönemi Üzerine Düşünceler, Karahan Kitabevi, Adana.

KÖSEOĞLU, Erhan (2019), “Organizasyonları Yönetmek: Çevik Bir Şirket Olmak Neden Bu Kadar Zor?”, Harvard Business Review Türkiye, https://hbrturkiye.com/blog/cevik-bir-sirket-olmak-neden-bu-kadarzor (Erişim Tarihi: 02.11.2020).

KÜLTER DEMIRGÜNEŞ, Banu (2015), "Sosyal Sorumluluk Projelerine Yönelik Tutumun, Satın Alma Davranışı ve Satın Alma Niyeti Üzerindeki Etkisi”, Hacettepe Üniversitesi İktisadi ve İdari Bilimler Fakültesi Dergisi, S.33(3), ss.47-74.

SLADEK, Sarah ve GRABINGER, Alyx (2016), Gen Z: The First Generation of The 21st Century Has Arrived!, XYZ University Publisher, Virginia (USA), https://www.xyzuniversity.com/wpcontent/uploads/2018/08/GenZ_Final-dl1.pdf (Erişim Tarihi: 02.11.2020).

STATEOFAGILE (2020), “Annual State of Agile Report for 2015”, E-Report, https://stateofagile.com (Erişim Tarihi: 02.11.2020).

STATEOFAGILE (2020), “Annual State of Agile Report for 2016”, E-Report, https://stateofagile.com (Erişim Tarihi: 02.11.2020).

STATEOFAGILE (2020), “Annual State of Agile Report for 2017”, E-Report, https://stateofagile.com (Erişim Tarihi: 02.11.2020).

STATEOFAGILE (2020), “Annual State of Agile Report for 2018”, E-Report, https://stateofagile.com (Erişim Tarihi: 02.11.2020).

STATEOFAGILE (2020), “Annual State of Agile Report for 2019”, E-Report, https://stateofagile.com (Erişim Tarihi: 02.11.2020).

STATEOFAGILE (2020), “Annual State of Agile Report for 2020”, E-Report, https://stateofagile.com (Erişim Tarihi: 02.11.2020).

STATEOFAGILE (2020), Stateofagile Corporate Website, https://stateofagile.com (Erişim Tarihi: 15.11.2020).

TANOĞLU, İsmail Murat (2018), “Çevik Üretim ve Bir Uygulama Çalı̧̧ması”, Yüksek Lisans Tezi, Necmettin Erbakan Üniversitesi, Konya.

VARGO, Stephen L. ve LUSCH, Robert F. (2017), "Service-Dominant Logic 2025”, International Journal of Research in Marketing, S.34(1), ss.46-67.

WANG, Qian, DOU, Junsheng ve JIA, Shenghua (2016), "A Meta-Analytic Review of Corporate Social Responsibility And Corporate Financial Performance: The Moderating Effect of Contextual Factors", Business \& Society, S.55(8), ss.1083-1121.

WYSOCKI, Robert K. (2014), Effective Project Management: Traditional, Agile, Extreme, Wiley Publishing Inc., Indianapolis, 5th Edition.

YAPAR, Tayfun (2015), "Motivasyonun İş̧ Verimliliği Üzerine Etkisi”, Yüksek Lisans Tezi, İstanbul Üniversitesi Sosyal Bilimler Enstitüsü, İstanbul.

YILMAZ, Birkan (2016), "Personel Memnuniyetinin İş Verimliliği Üzerine Etkisi", Yüksek Lisans Tezi, İstanbul Gelişim Üniversitesi Sosyal Bilimler Enstitüsü, İstanbul.

YUSUF, Gör ve TEKIN, Bilgehan (2018), “Kurumsal Sosyal Sorumluluk Kavramının Karlılık ile İlişkisi Üzerine Bir Çalışma: Bist 100 Örneği”, Sosyal Araştırmalar ve Davranış Bilimleri Dergisi, S.4(5), ss.18-30. 